\title{
SEROTONIN-INDUCED PROTEIN PHOSPHORYLATION IN A LOBSTER NEUROMUSCULAR PREPARATION ${ }^{1}$
}

\author{
MICHAEL F. GOY, ${ }^{2}$ THOMAS L. SCHWARZ, ${ }^{3}$ AND EDWARD A. KRAVITZ \\ Department of Neurobiology, Harvard Medical School, Boston, Massachusetts 02115
}

Received January 3, 1983; Revised August 24, 1983; Accepted August 25, 1983

\begin{abstract}
Three substances believed to be neurohormones in the lobster-serotonin, octopamine, and proctolin-can modulate the physiology of the dactyl opener muscle of the lobster walking leg. All three act directly on muscle fibers to cause long-lasting contractures. In addition, serotonin enhances the release of transmitter from the excitatory and inhibitory axons that innervate the muscle.

We now report that serotonin, applied to intact nerve-muscle preparations, increases the phosphorylation of a soluble 29,000 -dalton protein by as much as 20 -fold. In two respects the phosphorylation parallels the physiological effects of serotonin: both have a slow time course, and both are caused by low concentrations of serotonin (thresholds of approximately $10^{-8} \mathrm{M}$ ).

The 29,000-dalton protein is present in many lobster tissues, including thoracic ganglia, gills, and several different muscles. This suggests that the phosphorylation participates in some aspect of metabolism common to many types of cells, rather than in an activity unique to nerve or muscle. The function of the phosphorylated protein remains unknown.

Several lines of evidence suggest that the phosphorylation is mediated by a cyclic nucleotide, probably cyclic AMP. (1) Adding cyclic AMP or cyclic GMP to nerve-muscle homogenates leads to the phosphorylation. (2) Adding 8-Br-cyclic AMP or 8-Br-cyclic GMP to intact preparations leads to the phosphorylation. (3) In intact tissue, forskolin, an adenylate cyclase activator, and isobutylmethylxanthine, a phosphodiesterase inhibitor, increase cyclic AMP and cyclic GMP and also cause the phosphorylation. (4) Serotonin increases cyclic AMP in intact preparations. (5) RMI 12,330A, which blocks the serotonin-induced cyclic AMP increase, also blocks the phosphorylation. (6) Serotonin has no detectable effect on cyclic GMP. This suggests that cyclic AMP, and not cyclic GMP, is the second messenger that mediates phosphorylation in vivo.

In contrast, calcium is not likely to mediate the phosphorylation. Agents that block calcium channels do not block the serotonin-induced phosphorylation, and agents that increase sarcoplasmic calcium do not cause it. Furthermore, calcium does not induce the phosphorylation in a homogenate.

One of the other modulators, proctolin, does not increase cyclic AMP or cause the phosphorylation even at concentrations $10^{6}$-fold greater than the hormone's threshold for producing contractures. The third modulator, octopamine, causes small increases in cyclic AMP and is a weak agonist of the phosphorylation. Neither proctolin nor octopamine alters cyclic GMP levels.
\end{abstract}

Synaptic physiologists have described a class of hormones and neurosecretory products, often called modu-

\footnotetext{
${ }^{1}$ We would like to thank Deirdre Crommie and Charlotte Menzel for excellent technical assistance. We also thank Michael LaFratta, Joseph Gagliardi, Delores Cox, and David Kravitz for their help. This work was supported by National Institutes of Health Grants NS07848 and NS02253. M. F. G. held a Muscular Dystrophy Association postdoctoral fellowship and also received support from National Institutes of Health Training Grant NS07112. T. L. S. was supported by National Institutes of Health Training Grant NS07112.

${ }^{2}$ To whom correspondence should be addressed.

${ }^{3}$ Present address: Department of Physiology, University of California, San Francisco, CA 94143.
}

lators, that do not act like conventional transmitters. The effects of modulators are generally long-lasting, are not necessarily confined to synaptic regions, and often do not involve significant changes in the membrane potential of target cells (Kupfermann, 1979).

We have been studying the modulation of a simple nerve-muscle preparation-the dactyl opener muscle from the walking leg of the lobster, Homarus americanus. Just one excitatory and one inhibitory axon innervate the opener muscle (Wiersma and Ripley, 1952). The transmitter of the inhibitory axon is $\gamma$-aminobutyric acid (Takeuchi and Takeuchi, 1965; Otsuka et al., 1966), and the excitatory transmitter is likely to be glutamate 
(Kravitz et al., 1970; Kawagoe et al., 1982). In addition, the physiology of the preparation is modulated by three substances - serotonin, octopamine, and a proctolin-like peptide-which are released from peripheral neurosecretory structures and can reach the muscle through the circulatory system (Maynard and Welsh, 1959; Welsh and Moorhead, 1960; Evans et al., 1975; Sullivan et al., 1977; Sullivan, 1979; Kravitz et al., 1980; Livingstone et al., 1981).

The muscle itself and the terminals of the excitatory and inhibitory axons are each influenced by one or more of the modulators. On the muscle fibers, all three modulators produce similar physiological effects (Florey and Florey, 1954; Grundfest and Reuben, 1961; Evans et al., 1975; Battelle and Kravitz, 1978; Kravitz et al., 1980; Schwarz et al., 1980): (a) a Ca ${ }^{2+}$-dependent contracture which rises slowly and persists for as long as $1 \mathrm{hr}$ after removing the modulator, and $(b) \mathrm{Ca}^{2+}$-dependent action potentials where formerly there were none. For serotonin, these physiological changes have been examined under voltage clamp. An increase in an inward current was observed that probably represents alteration of a voltage-dependent $\mathrm{Ca}^{2+}$ conductance (Kravitz et al., 1980).

In contrast to the muscle fibers, the excitatory and inhibitory nerve terminals appear to be affected only by serotonin, which causes long-lasting increases in both spontaneous and evoked release of transmitter (Grundfest and Reuben, 1961; Dudel, 1965; Kravitz et al., 1980; Schwarz et al., 1980; Glusman and Kravitz, 1982; S. Glusman, M. F. Johnston, and E. A. Kravitz, manuscript in preparation). In similar preparations from the crayfish, however, octopamine also slightly enhances release of the excitatory transmitter (Breen and Atwood, 1983; Fischer and Florey, 1983).

We are interested in identifying the biochemical mechanisms that underlie modulation of this system. In other systems, protein phosphorylation has been linked to the same physiological processes that we are studying: muscle contraction and transmitter release (Bárány and Bárány, 1980; Tada and Katz, 1982; Kennedy, 1983). Both serotonin and octopamine may use such a mechanism. Both have been reported to alter cyclic nucleotide levels in various tissues (Greengard, 1978; Lingle et al., 1982), including the lobster muscle that we are studying (Battelle and Kravitz, 1978), and to cause phosphorylation of specific proteins. In the facial motor nucleus of the ral, serotonin increased phosphorylation of several proteins, including proteins $\mathrm{Ia}$ and $\mathrm{Ib}\left(M_{\mathrm{r}}=80,000\right.$ and 86,000 ) (Dolphin and Greengard, 1981a, b). In the abdominal ganglion of Aplysia californica, serotonin caused the phosphorylation of proteins with $M_{\mathrm{r}}$ ranging from 26,000 to 137,000 (Levitan and Barondes, 1974; Levitan et al., 1974; Lemos et al., 1982; Paris et al., 1982). Octopamine also caused the phosphorylation of one of these proteins $\left(M_{\mathrm{r}}=120,000\right)$ (Levitan and Barondes, 1974; Levitan et al., 1974). Some of the best evidence associating cyclic nucleotide-mediated phosphorylation with the physiological actions of serotonin has been obtained in this Aplysia ganglion (Klein and Kandel, 1978; Drummond et al., 1980; Castellucci et al., 1980, 1982; Adams and Levitan, 1982; Lemos et al., 1982; Paris et al., 1982).
In this paper we report the serotonin-induced phosphorylation of a 29,000-dalton protein in a lobster neuromuscular preparation and discuss the role of cyclic nucleotides in this phosphorylation. In addition, we have determined the subcellular distribution of the 29,000dalton protein and have surveyed other lobster tissues for its presence.

\section{Materials and Methods}

We obtained materials from the following sources: the triethyl ammonium salt of $\gamma-\left[{ }^{32} \mathrm{P}\right]$ ATP from Amersham Searle $\left(10\right.$ to $30 \mathrm{Ci} / \mathrm{mmol}$, approximately $4 \times 10^{-5} \mathrm{M}$ in $50 \%$ ethanol-this was dried under $\mathrm{N}_{2}$ just prior to use and resuspended to approximately $8 \times 10^{-5} \mathrm{M}$ in the homogenization buffer described below); AG 1-X8 ion exchange resin (formate, 100 to 200 mesh) and electrophoresis reagents from BioRad; forskolin and chymotrypsin from Calbiochem; RMI 12,330A from MerrillNational Laboratories; cholera toxin from SchwartzMann; $\mathrm{Na}_{3}{ }^{32} \mathrm{PO}_{4}$ (approximately $9000 \mathrm{Ci} / \mathrm{mmol}$ ), $\left[{ }^{3} \mathrm{H}\right]$ water $(0.25 \mathrm{mCi} / \mathrm{ml}),\left[{ }^{14} \mathrm{C}\right]$ inulin $(2.1 \mathrm{mCi} / \mathrm{gm})$, and $\mathrm{ra}-$ dioimmunoassay kits for cyclic AMP and cyclic GMP from New England Nuclear; trypsin from Miles Laboratories; proctolin from Penninsula Laboratories; serotonin creatinine sulfate, D,L-octopamine hydrochloride, 8-Br-cyclic AMP, 8-Br-cyclic GMP, and Staphylococcus aureus V8 protease from Sigma; isobutylmethylxanthine (IBMX) from Aldrich; and caffeine from Eastman.

Phosphorylation of the intact opener muscle. Intact opener muscles were dissected as described previously (Otsuka et al., 1966). The muscles contained a short section of the attached nerve and remained partially encased in exoskeleton since the exoskeleton cannot be completely removed without damaging muscle fibers. Each preparation was placed in $1 \mathrm{ml}$ of cold saline (462 $\mathrm{mM} \mathrm{NaCl}, 16 \mathrm{mM} \mathrm{KCl}, 26 \mathrm{mM} \mathrm{CaCl}_{2}, 8 \mathrm{mM} \mathrm{MgCl}_{2}, 11$ $\mathrm{mM}$ glucose, $10 \mathrm{~mm}$ Tris-maleate, $\mathrm{pH}$ 7.4) in a capped glass vial on a rotating wheel at $12^{\circ} \mathrm{C}$. After $1 \mathrm{hr}$ the saline was replaced by $1 \mathrm{ml}$ of fresh saline at $12^{\circ} \mathrm{C}$ containing $0.25 \mathrm{mCi}$ of ${ }^{32} \mathrm{P}_{\mathrm{i}}$ (approximately $3 \times 10^{-9} \mathrm{M}$ final concentration). The tissue was incubated in this solution for $4 \mathrm{hr}$ to permit phosphate uptake and labeling of intracellular ATP and phosphoproteins. Four hours allowed sufficient incorporation of ${ }^{32} \mathrm{P}$ into phosphoproteins to obtain autoradiograms with conveniently short exposure times, but incubations of less than $4 \mathrm{hr}$ gave similar results. Following this labeling period, drugs or hormones were added for a further period, as described under "Results." Then each muscle was rinsed briefly in nonradioactive saline (containing the test drug or hormone where appropriate) and placed in $4 \mathrm{ml}$ of methanol at $-80^{\circ} \mathrm{C}$. The frozen muscles, submerged in methanol, were stored at $-20^{\circ} \mathrm{C}$ overnight to permit freeze-substitution of methanol for the water in the tissue (Pearse, 1980 ), thus denaturing protein and inactivating kinases, phosphatases, and proteases.

The dehydrated tissue was dissected free of exoskeleton and tendon and was homogenized in $1 \mathrm{ml}$ of ice-cold $\mathrm{CHCl}_{3}: \mathrm{CH}_{3} \mathrm{OH}: \mathrm{H}_{2} \mathrm{O}$ (5:10:4) to extract phospholipids (Bligh and Dyer, 1959). After $15 \mathrm{~min}$ on ice, insoluble material was collected by centrifugation ( 2 to $3 \mathrm{sec}$ at approximately $8000 \times \mathrm{g}$ in a Beckman Microfuge) and resuspended in $0.5 \mathrm{ml}$ of ice-cold $6 \%$ trichloroacetic acid 
(TCA) to extract free phosphate and low molecular weight metabolites. After an additional $15 \mathrm{~min}$ on ice, the precipitate was collected by centrifugation, washed again with $0.5 \mathrm{ml}$ of ice-cold $6 \% \mathrm{TCA}$, and washed twice with $0.5 \mathrm{ml}$ of ice-cold acetone. It was then resuspended in $1.5 \mathrm{ml}$ of electrophoresis buffer (Laemmli, 1970) with the mercaptoethanol concentration reduced to $1 \%$ to minimize interference with subsequent protein determinations. To solubilize proteins, samples were heated to $100^{\circ} \mathrm{C}$ for $80 \mathrm{~min}$ in sealed tubes. Insoluble material was removed by centrifugation ( $10 \mathrm{~min}$ at approximately 8000 $\times g$ ). Five microliters of each sample were then placed in a glass tube, heated to $100^{\circ} \mathrm{C}$ for $60 \mathrm{~min}$ to evaporate mercaptoethanol, and analyzed for protein content (Lowry et al., 1951).

Phosphorylation of homogenates. For experiments with homogenates, four to six intact preparations were rinsed with ice-cold homogenization buffer $(50 \mathrm{mM}$ Na-HEPES, $\mathrm{pH}$ 7.4, $200 \mathrm{~mm} \mathrm{KCl,} 10 \mathrm{~mm} \mathrm{MgCl}_{2}, 1 \mathrm{~mm}$ EGTA, $1 \mathrm{mM}$ glutathione), and the nerves and muscles were removed from the exoskeleton, pooled, and homogenized on ice in 600 to $900 \mu \mathrm{l}$ of the same buffer (to give approximately $10 \mathrm{mg}$ of protein $/ \mathrm{ml}$ ). For each sample $24 \mu \mathrm{l}$ of homogenate were placed at room temperature in a vial containing $4.4 \mu \mathrm{l}$ of either cyclic AMP, cyclic GMP, or $\mathrm{CaCl}_{2}$ solutions, or distilled water. Three minutes later $15 \mu \mathrm{l}$ (approximately $30 \mu \mathrm{Ci}$ ) of a $\gamma-\left[{ }^{32} \mathrm{P}\right] \mathrm{ATP}$ solution were added to each sample, to give approximately $3 \times 10^{-5} \mathrm{M}$ ATP. After an additional $5 \mathrm{~min}$ the reaction was stopped by adding $500 \mu$ l of boiling electrophoresis buffer (Laemmli, 1970 , except that mercaptoethanol was reduced to $0.1 \%$ ), and the samples were boiled for $15 \mathrm{~min}$. Insoluble material was removed, and the protein concentration in each sample was determined as described above.

Gel electrophoresis and autoradiography. For each sample, $50 \mu \mathrm{g}$ of protein were electrophoretically separated (Laemmli, 1970) on a $0.75-\mathrm{mm}$-thick polyacrylamide slab gel with an $8-\mathrm{cm}$ stacking gel ( $4 \%$ acrylamide, $0.1 \%$ bisacrylamide) and a 24-cm resolving gel (either $15 \%$ acrylamide, $0.4 \%$ bisacrylamide or a linear gradient of 6 to $15 \%$ acrylamide, 0.16 to $0.4 \%$ bisacrylamide). Gels were stained for protein (Fairbanks et al., 1971) and dried on Whatman $3 \mathrm{MM}$ filter paper (Hoefer slab gel dryer model SE540). Autoradiography was performed with pre-exposed Kodak X-AR5 film at $-80^{\circ} \mathrm{C}$ and DuPont Cronex Lightning Plus Intensifying Screens (Laskey and Mills, 1977).

For quantitative determinations, autoradiograms from $15 \%$ gels were scanned with a Schoeffel SD 3000 spectrodensitometer. The area of the peak of interest $(29,000$ daltons) was determined and corrected for variations in labeling from muscle to muscle by normalizing to the summed areas of three nearby peaks that appeared to be unaffected by any of the stimuli tested. Whenever possible, we used a pair of right and left legs from a single animal, one leg serving as a control and the other as an experimental sample.

Fractionation of the homogenate. The effects of cyclic nucleotides on phosphorylation in the muscle were examined in a homogenate that was fractionated by centrifugation. From each fraction, three portions were given either $10^{-4} \mathrm{M}$ cyclic AMP, $10^{-4} \mathrm{M}$ cyclic GMP, or water and tested for phosphorylation as described in the pre- ceding section. The details of the fractionation are as follows. Six muscles were homogenized in $900 \mu \mathrm{l}$ of icecold homogenization buffer and sonicated for $2 \mathrm{~min}$, cooled on ice for $2 \mathrm{~min}$, and sonicated again for $2 \mathrm{~min}$ (ultrasonic cleaner, Laboratory Supplies Co., Inc.). Three 24- $\mu$ l portions were tested for phosphorylation as described above, and the remainder of the homogenate was centrifuged for $40 \mathrm{~min}$ at $600 \times \mathrm{g}$. The pellet of this lowspeed centrifugation was resuspended in $600 \mu \mathrm{l}$ of icecold homogenization buffer. Three $24-\mu$ l portions from the pellet and supernatant fractions were tested for phosphorylation. The remainder of the supernatant fraction was centrifuged at $96,000 \times g$ for either 15 or $60 \mathrm{~min}$. The latter yielded a soluble fraction that contains less than $1 \%$ of the lipid phosphate present in the original homogenate and has a protein to lipid ratio 14 -fold greater than the unfractionated homogenate. The pellet of this high-speed centrifugation was resuspended by sonication in $105 \mu \mathrm{l}$ of ice-cold homogenization buffer, and three $24-\mu \mathrm{l}$ portions were tested for phosphorylation. Finally, three $48-\mu$ l portions of the high-speed supernatant fraction were tested for phosphorylation (doubling the volume of everything in the assay except the electrophoresis buffer, which was increased 1.3-fold).

Prolein phosphorylation in other tissues. Freshly dissected tissues were weighed, rinsed in ice-cold homogenization buffer, and homogenized on ice in homogenization buffer ( $3 \mu \mathrm{l} / \mathrm{mg}$ wet weight for most tissues; $1 \mu \mathrm{l} / \mathrm{mg}$ wet weight for nervous tissue). Cyclic nucleotide-dependent protein phosphorylation was assayed in whole homogenates or in some cases in a high-speed supernatant fraction prepared from the homogenates by the two centrifugation steps described above.

Protcolytic digestion of the 29,000-dalton protein. Samples containing protein to be digested were separated by electrophoresis, briefly stained and destained (no more than $30 \mathrm{~min}$ in staining solution and $60 \mathrm{~min}$ in destaining solution to minimize acid hydrolysis of protein; Cleveland et al., 1977), dried, and exposed to film for autoradiography. The positions of radioactive proteins were located by aligning each gel with its autoradiogram. The pieces of gel containing the proteins of interest were cut out and rehydrated for $30 \mathrm{~min}$ in $1 \mathrm{ml}$ of rehydration buffer $(0.125 \mathrm{~m}$ Tris-Cl, $\mathrm{pH}$ 6.8, 0.1\% SDS, $1 \mathrm{~mm}$ EDTA, $0.001 \%$ bromphenol blue; Matsumura et al., 1977). Rehydrated gel pieces were placed in the wells of a $1.5-\mathrm{mm}$ thick $15 \%$ gel, surrounded with approximately $50 \mu \mathrm{l}$ of rehydration solution containing $20 \%$ glycerol, and overlayered with $10 \mu \mathrm{l}$ of rehydration solution containing $10 \%$ glycerol and trypsin, chymotrypsin, or S. aureus V8 protease at concentrations ranging from 5 to $1000 \mu \mathrm{g} / \mathrm{ml}$ (Cleveland et al., 1977). Electrophoresis was performed as usual, except that when the tracking dye was about 1 $\mathrm{cm}$ into the stacking gel the current was turned off for $30 \mathrm{~min}$. Radioactive fragments were located by autoradiography.

Cyclic nucleotide measurements in the dactyl opener muscle. Intact opener muscles were dissected and incubated as described for phosphorylation experiments except that after $1 \mathrm{hr}$ at $12^{\circ} \mathrm{C}$ each muscle was placed in normal saline (or saline containing 0.5 mM IBMX) instead of saline containing ${ }^{32} \mathrm{P}_{\mathrm{i}}$. During the next $4 \mathrm{hr}$, a drug or hormone was added as indicated under "Results." 
At the end of the incubation the muscle was quick-frozen in methanol at $-80^{\circ} \mathrm{C}$, cut free from the exoskeleton, and homogenized in $0.8 \mathrm{ml}$ of ice-cold $6 \%$ TCA. After $15 \mathrm{~min}$ at $4^{\circ} \mathrm{C}$ the homogenate was centrifuged for $5 \mathrm{sec}$ in a Beckman Microfuge. The pellet was washed with an additional $0.2 \mathrm{ml}$ of ice-cold $6 \% \mathrm{TCA}$, centrifuged, and the two TCA-soluble supernatant fractions were combined. The pellet was dissolved in $1.5 \mathrm{ml}$ of $1 \mathrm{~N} \mathrm{NaOH}$, and total protein was determined (Lowry et al., 1951). The combined supernatant fractions were applied to a cation exchange column (AG-1-X8 formate, 100 to 200 mesh, $5 \times 60 \mathrm{~mm}$ ) that had been equilibrated with $0.1 \mathrm{~N}$ formic acid. The column was washed with $6 \mathrm{ml}$ of $0.1 \mathrm{~N}$ formic acid, then with $20 \mathrm{ml}$ of $1 \mathrm{~N}$ formic acid, which eluted cyclic AMP, and finally with $20 \mathrm{ml}$ of $4 \mathrm{~N}$ formic acid, which eluted cyclic GMP (Haymovits and Scheele, 1976). The cyclic nucleotide fractions were dried at $70^{\circ} \mathrm{C}$ under vacuum (Rotovap) to remove formic acid and were resuspended in $2 \mathrm{ml}$ of $0.05 \mathrm{M}$ sodium acetate, $\mathrm{pH} 6.2$. Samples of 20 to $40 \mu \mathrm{l}$ were analyzed for cyclic nucleotide content by radioimmunoassay, using procedures and materials from New England Nuclear. The cyclic GMP samples were acetylated prior to analysis to increase the sensitivity of the assay. Results are expressed as picomoles of cyclic nucleotide per milligram of protein.

Measurement of the intracellular volume of the dactyl opener muscle. Six muscles were incubated in $1 \mathrm{ml}$ of saline containing $1 \mu \mathrm{Ci}$ of $\left[{ }^{3} \mathrm{H}\right]$ water and $1 \mu \mathrm{Ci}$ of $\left[{ }^{14} \mathrm{C}\right]$ inulin for $5 \mathrm{hr}$, at which time both isotopes had reached a constant level in the tissue. The muscles were then blotted dry and homogenized in $0.5 \mathrm{ml}$ of water. Radioactivity in each muscle was measured with a Packard TriCarb Liquid Scintillation Counter. Intracellular volume, calculated as the difference between total volume (determined from the ${ }^{3} \mathrm{H}$ content of the tissue) and extracellular volume (determined from the ${ }^{14} \mathrm{C}$ content of the tissue), was $16 \pm 0.7 \mu \mathrm{l}$ (mean \pm SEM, $n=6$ ).

\section{Results}

Effects of serotonin on protein phosphorylation. The lobster neuromuscular preparation incorporates ${ }^{32} \mathrm{P}$ into a variety of proteins which are electrophoretically separated best on a gradient gel (Fig. 1). If the tissue is exposed to serotonin during the labeling period, a consistent increase in incorporation is observed in the region of the gel just below the 30,000-dalton molecular weight marker protein. Small changes are often observed in the labelling intensity of other bands on the gel; however, these changes are not reproducible. The total amount of ${ }^{32} \mathrm{P}$ incorporated into proteins also frequently differs from sample to sample, but these differences do not correlate with the presence of serotonin.

A $15 \%$ acrylamide gel, although it does not adequately separate high molecular weight components, provides optimal resolution of the region affected by serotonina prominent band is seen that is scarcely labeled in an untreated muscle (Fig. 2). The apparent $M_{\mathrm{r}}$ of this band is $\sim 29,000$. To verify that it is a protein, we cut it from a dried gel and showed that it is susceptible to digestion by protease (see Fig. 7).

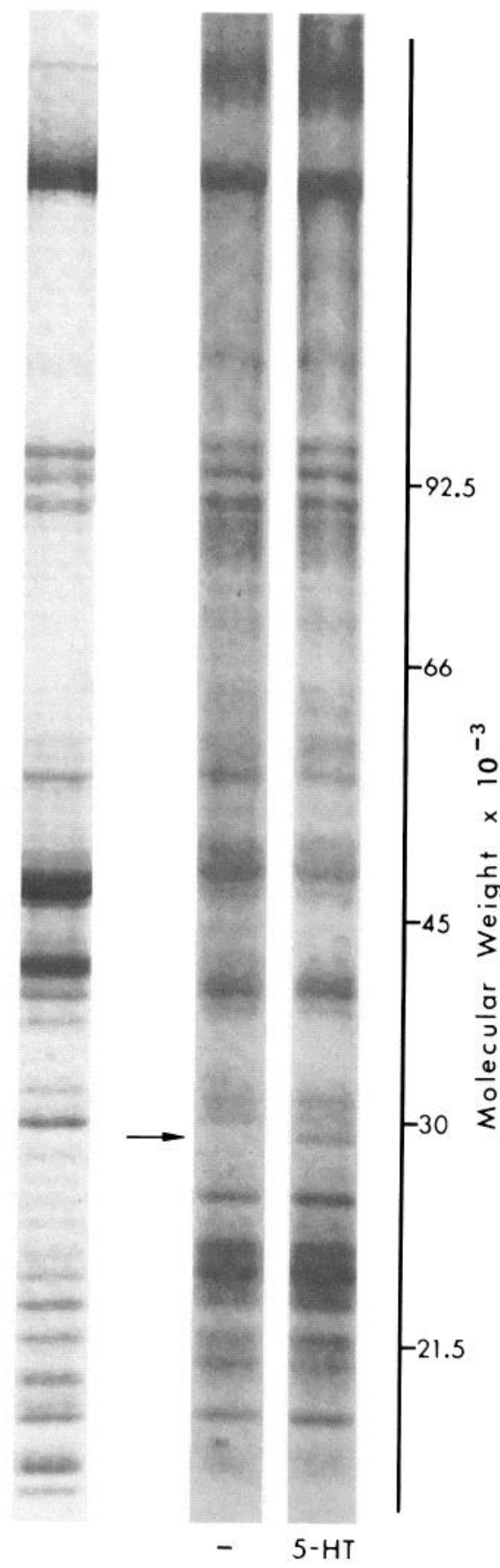

Figure 1. Electrophoretic separation of proteins from the lobster opener muscle on a $24-\mathrm{cm} 6$ to $15 \%$ linear gradient acrylamide gel. $a$, Protein stain; $b$, autoradiogram showing the effect of serotonin on the 29,000-dalton protein. A pair of muscles was incubated for $4 \mathrm{hr}$ in saline containing ${ }^{32} \mathrm{P}_{\mathrm{i}}$. Serotonin $(5-H T), 10^{-6} \mathrm{M}$, was added to the labeling medium of one of the muscles, and both were incubated for a further $15 \mathrm{~min}$. The muscles were frozen and prepared for electrophoresis as described under "Materials and Methods." The molecular weight scale was established with the following proteins: phosphorylase b $(92,500)$, bovine serum albumin $(66,000)$, ovalbumin $(45,000)$, carbonic anhydrase $(30,000)$, and soybean trypsin inhibitor $(21,500)$. The arrow marks the position of the $29,000-$ dalton protein. 


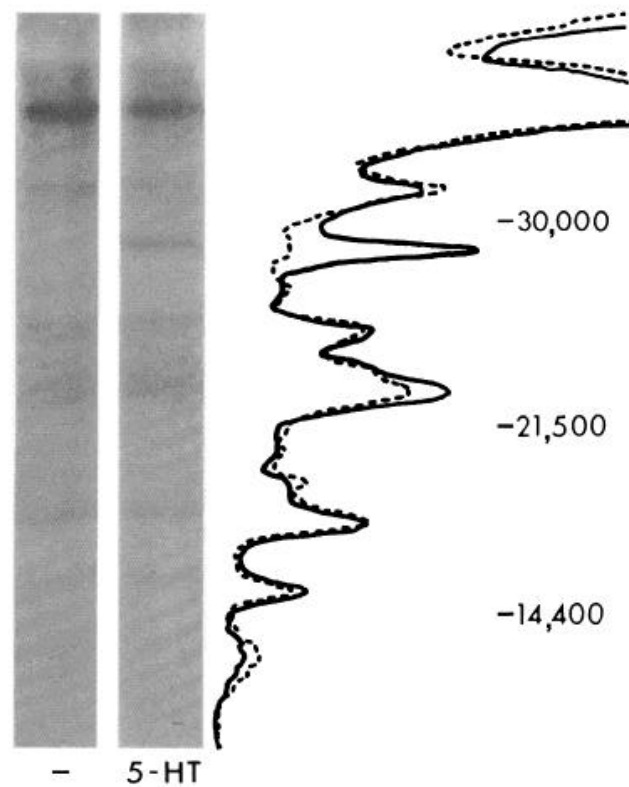

Figure 2. The effect of $10^{-6} \mathrm{M}$ serotonin on the phosphorylation of the 29,000-dalton protein. Autoradiograms show the region of a $15 \%$ acrylamide gel that surrounds the 29,000 dalton protein. The samples were prepared as described in Figure 1. In the densitometric scans of these autoradiograms, the solid line represents the serotonin $(5-H T)$-treated preparation and the broken line represents an untreated control. The positions of carbonic anhydrase (30,000 daltons), soybean trypsin inhibitor (21,500 daltons), and lysozyme (14,400 daltons) are indicated.

We do not yet know whether the protein resides in nerve, muscle, or both; however, to be located exclusively in the neuronal elements, which are only a very small fraction of the tissue, the protein would have to be present in the terminals at a very high concentration. It is unlikely that contaminating connective tissue and blood clot are the source of the protein, since connective tissue and blood clot removed from the muscle did not show the serotonin-induced phosphorylation.

Some aspects of the induced phosphorylation correlate well with the physiological effects of serotonin. Phosphorylation is stimulated by low concentrations of serotonin; the threshold for a detectable effect is near $10^{-8} \mathrm{M}$ (Fig. 3 ). This is approximately the threshold at which changes in pre- and postsynaptic physiology can be detected (Battelle and Kravitz, 1978; Glusman and Kravitz, 1982). Higher concentrations of serotonin cause more phosphorylation until, at $10^{-6} \mathrm{M}$, a 10 - to 20 -fold increase is observed. Figure 4 shows the time course of phosphorylation. During continuous exposure to $10^{-6} \mathrm{M}$ serotonin, radioactive labeling of the 29,000 -dalton protein increases over a period of about $10 \mathrm{~min}$ and is maintained for at least $2 \mathrm{hr}$. The slow onset and long-lasting nature of the serotonin-induced phosphorylation are consistent with the slow, long-lasting physiological responses to the amine (Battelle and Kravitz, 1978; Glusman and Kravitz, 1982).

Effects of proctolin and octopamine on protein phosphorylation. Proctolin and octopamine also cause contrac- tures in this muscle (see the introduction). The threshold concentration for proctolin is $10^{-10} \mathrm{M}$ (Schwarz et al., 1980 ), and that for octopamine is $5 \times 10^{-8} \mathbf{M}$ (Kravitz et al., 1980). These contractions, like those induced by serotonin, are long-lasting; maximum tension is reached over 10 to $15 \mathrm{~min}$. In seven experiments, a 15-min exposure to proctolin, at concentrations ranging from 5 $\times 10^{-8} \mathrm{M}$ to $10^{-4} \mathrm{M}$, did not cause detectable phosphorylation of the 29,000-dalton protein (Fig. 5).

Results with octopamine have been more variable. A 15-min exposure to $10^{-6} \mathrm{M}$ octopamine, a concentration that causes large contractures, led to no detectable phosphorylation in six experiments (Fig. 5). Only at higher concentrations, ranging from $10^{-4} \mathrm{M}$ to $10^{-2} \mathrm{M}$, did we occasionally see a small amount of phosphorylation. Because cyclic AMP is likely to mediate the phosphorylation (see below), we tried to enhance the effect of octopamine by adding the phosphodiesterase inhibitor IBMX to the labeling medium. IBMX by itself caused detectable phosphorylation of the 29,000-dalton protein, and subsequent exposure to low concentrations of octopamine usually caused a further increase (Fig. 5). In six experi-

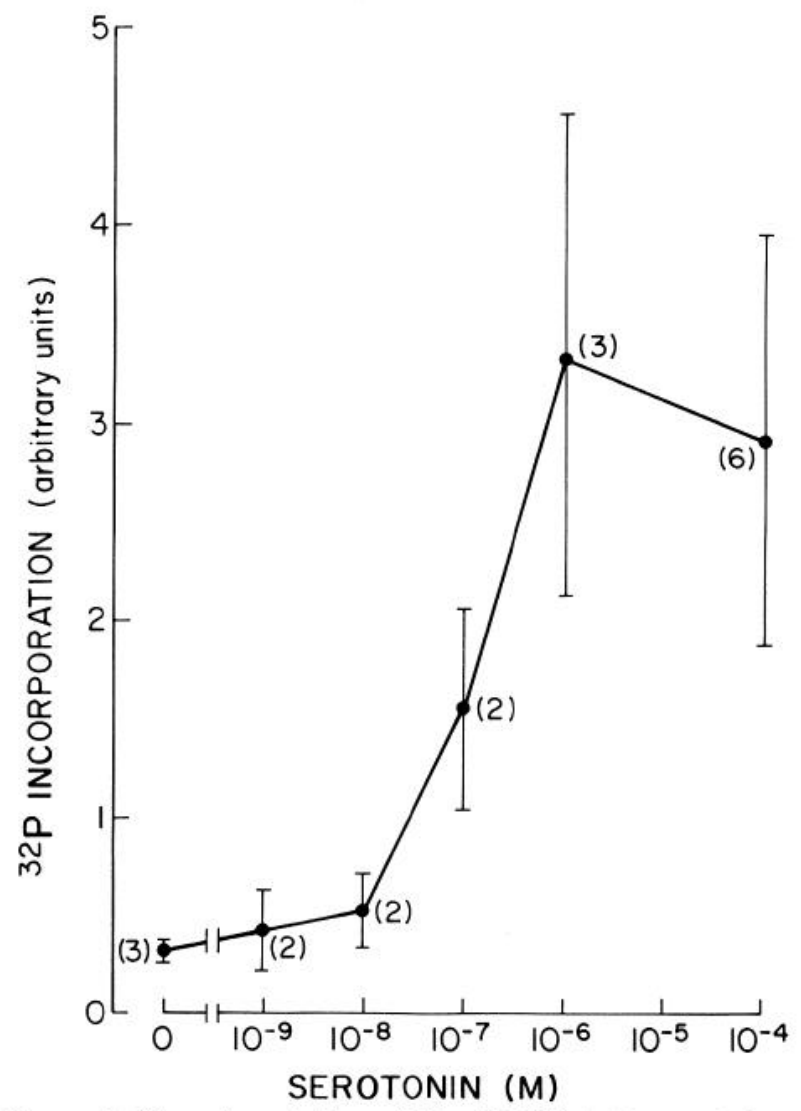

Figure 3. Phosphorylation of the 29,000-dalton protein as a function of serotonin concentration. The ordinate, in arbitrary units, gives the amount of phosphorylation of the 29,000-dalton protein, measured and normalized as described under "Materials and Methods." Each point is the mean value for the number of muscles shown in parentheses. Error bars indicate the standard deviation, or, in the case of duplicate determinations, the actual values for the two muscles. Muscles were incubated as described in Figure 1. Serotonin was applied for $15 \mathrm{~min}$. 


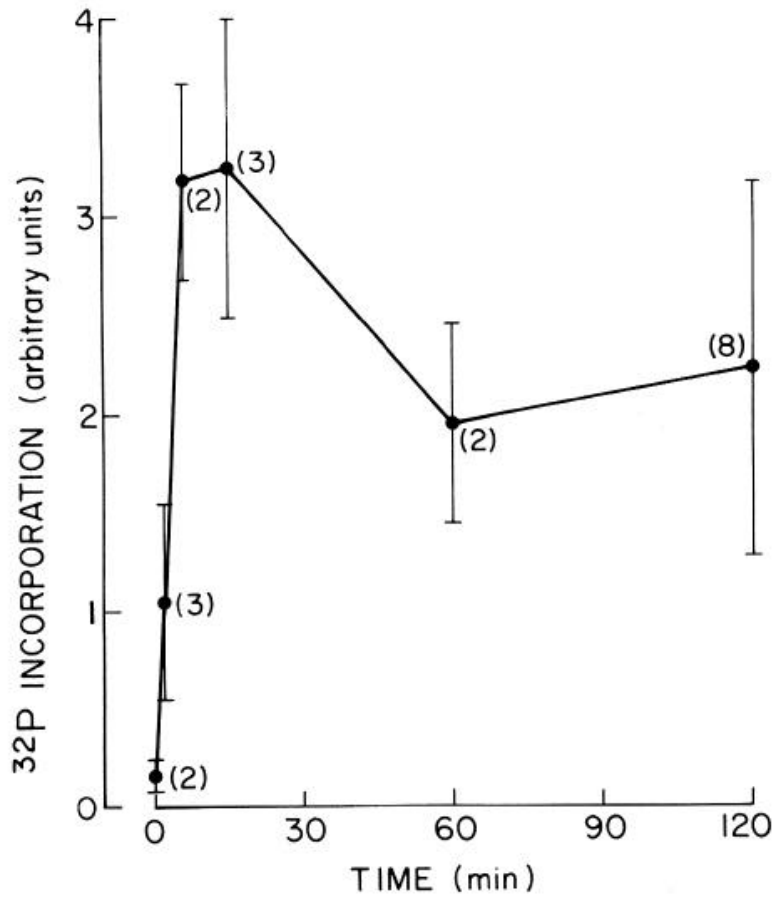

Figure 4. Time course of phosphorylation of the 29,000dalton protein. All muscles were incubated for a total of $4 \mathrm{hr}$ in saline containing ${ }^{32} \mathrm{P}_{\mathrm{i}}$. Serotonin $\left(10^{-6} \mathrm{M}\right)$ was added to the muscles for the final portion of this incubation. The abscissa indicates the length of time that each muscle was exposed to the hormone. The ordinate, in arbitrary units, indicates the relative amount of phosphorylation measured and normalized as described under "Materials and Methods." Data are taken from two experiments in which different peaks were used for normalization. To combine the two experiments, the data were scaled so that the means of the four 120 -min points from each experiment were equal. Each point is the mean value for the number of muscles shown in parentheses. Error bars indicate the standard deviation, or, in the case of duplicate determinations, the actual values for the two muscles.

ments with $0.5 \mathrm{mM}$ IBMX, phosphorylation caused by $10^{-6}$ or $10^{-5} \mathrm{M}$ octopamine was $220 \pm 51 \%$ of control (mean \pm SEM). Four of these experiments showed 2- to 5 -fold stimulation by octopamine, one showed a small increase, and one showed no change. In contrast, $10^{-6} \mathrm{M}$ proctolin, even in the presence of IBMX, fails to influence phosphorylation of the 29,000-dalton protein (105 $\pm 6 \%$ of control, $n=3$ ).

Besides the 29,000-dalton protein, no other phosphoprotein was noticeably affected by proctolin or octopamine, either with or without IBMX. However, a small effect would have been difficult to detect because of the variability from sample to sample.

Phosphorylation in homogenates. Phosphorylation in a homogenate of the dactyl opener muscle generally correlates well with phosphorylation in the intact preparation: each phosphoprotein in an autoradiogram of a sample from a ${ }^{32} \mathrm{P}_{\mathrm{i}}$-labeled muscle has a corresponding band in a sample from a homogenate given $\gamma-\left[{ }^{32} \mathrm{P}\right] \mathrm{ATP}$ (Fig. 6). There are, however, some disparities, of which the most conspicuous is a diffuse radioactive background that obscures high molecular weight proteins in intact preparations. In addition, there are differences in the intensity of labeling of particular proteins. These dissimilarities could arise from the breakdown of subcellular compartments in homogenates or from differences in the two experimental protocols (e.g., labeling time).

Cyclic AMP, cyclic GMP, and $\mathrm{Ca}^{2+}$ each affect the phosphorylation of proteins in the homogenate (Fig. 6). One striking effect is the increase in phosphorylation of a 29,000-dalton protein caused by both cyclic AMP and cyclic GMP but not by $\mathrm{Ca}^{2+}$. When run on the same gel, the 29,000-dalton phosphoprotein labeled in homogenates co-migrates with the phosphoprotein induced by serotonin in intact preparations.

Another effect that occurs in homogenates (Fig. 6) is a general decrease caused by $0.3 \mathrm{mM} \mathrm{Ca}^{2+}$ in the phosphorylation of many proteins. The significance of this decrease is unknown, but a similar observation has been made by others (Lemay et al., 1974; Jennings et al., 1982). In addition, both cyclic nucleotides often increase the phosphorylation of proteins with apparent $M_{\mathrm{r}}=$ 50,000 and 56,000 . The magnitude and reproducibility of the change in phosphorylation of these proteins, however, are not as great as the effect on the 29,000-dalton protein. Although we have not observed increases in phosphorylation of these two proteins in intact preparations when serotonin is applied, small changes in their phosphorylation may have gone undetected.

When the 29,000-dalton phosphoproteins evoked by cyclic AMP, cyclic GMP, and serotonin are cut from gels and digested with proteases $(0.5 \mathrm{mg} / \mathrm{ml}$ of trypsin, Fig. $7 a$, or $5 \mu \mathrm{g} / \mathrm{ml}$ of $S$. aureus V8 protease, data not shown),

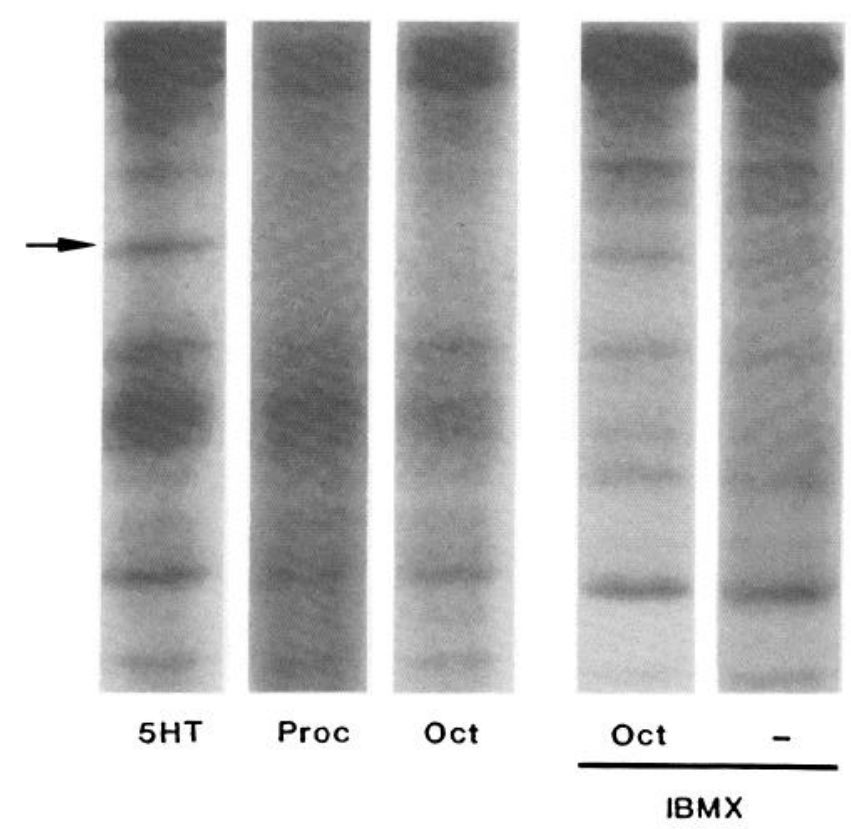

Figure 5. The effects of serotonin, proctolin, and octopamine on phosphorylation. Muscles were labeled for $4 \mathrm{hr}$ in saline containing ${ }^{32} \mathrm{P}_{\mathrm{i}}$ with or without $0.5 \mathrm{mM}$ IBMX and were exposed to $10^{-6} \mathrm{M}$ serotonin $(5 H T)$, proctolin (Proc), or octopamine $(O c t)$ for the last $15 \mathrm{~min}$ of the labeling period as indicated in the figure. The arrow marks the position of the 29,000-dalton protein. 


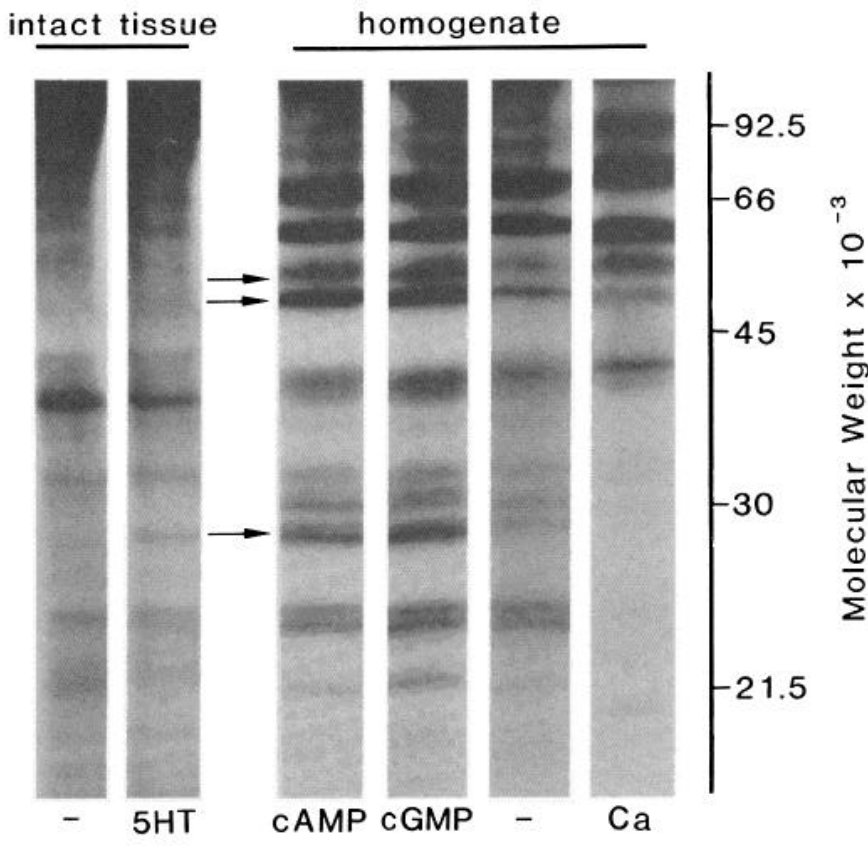

Figure 6. The effects of cyclic nucleotides and $\mathrm{Ca}^{2+}$ on phosphorylation in homogenates. Lanes 1 and 2 are autoradiograms of samples from intact preparations phosphorylated in the absence (-) or presence of $10^{-7} \mathrm{M}$ serotonin $(5 H T)$. Lanes 3 to 6 are from homogenates phosphorylated in the absence (-) or presence of $100 \mu \mathrm{M}$ cyclic AMP (cAMP), $100 \mu \mathrm{M}$ cyclic GMP $(c G M P)$, or $1.3 \mathrm{mM} \mathrm{CaCl}_{2}(\mathrm{Ca})$. Since $1 \mathrm{mM}$ EGTA is included in the homogenization buffer, the free $\mathrm{Ca}^{2+}$ concentration in the latter sample was approximately $0.3 \mathrm{mM}$. The lower arrow marks the position of the 29,000-dalton protein. The upper arrows mark 50,000- and 56,000-dalton proteins whose phosphorylation is stimulated by the cyclic nucleotides. Although in this experiment other effects on phosphorylation were seen (e.g., increased phosphorylation of the 56,000 -dalton protein by $\mathrm{Ca}^{2+}$ or the 43,000 -dalton protein by cyclic GMP), these effects do not occur consistently.

they yield the same patterns of radioactive fragments. This demonstrates that all three agents affect the same protein and also that the phosphorylations occur at the same or nearby sites. In addition, the phosphorylations caused by cyclic AMP and cyclic GMP appear identical when treated with $1 \mathrm{mg} / \mathrm{ml}$ of $S$. aureus V8 protease (Fig. $7 b$ ) and $1 \mathrm{mg} / \mathrm{ml}$ of chymotrypsin (data not shown). Thus, if the two cyclic nucleotides produce phosphorylation at distinct sites, the sites must be close enough that they are not separated by these digestions.

The dose response relationships for cyclic AMP and cyclic GMP are shown in Figure 8. The effect of the cyclic nucleotides is large: at the highest concentrations tested $\left(10^{-3} \mathrm{M}\right)$, phosphate incorporation was increased by an average of 6.2 -fold (cyclic GMP) and 4.2 -fold (cyclic AMP) above control. Cyclic GMP is more potent than cyclic AMP in these homogenates; cyclic GMP is effective at lower concentrations and causes more phosphorylation than cyclic AMP at concentrations of $10^{-6}$ $\mathrm{M}$ and higher.

Effect of serotonin, octopamine, and proctolin on cyclic nucleotide levels. Because cyclic AMP and cyclic GMP are capable of inducing the phosphorylation in homoge- nates, we investigated whether either of these cyclic nucleotides is increased by serotonin, octopamine, or proctolin in intact preparations. Muscles were exposed to the hormones for $15 \mathrm{~min}$. This period is sufficient for both the physiological effects of the hormones and the serotonin-induced phosphorylation of the 29,000-dalton protein to reach their maxima. Measurements were made in the absence and the presence of $0.5 \mathrm{mM}$ IBMX, a phosphodiesterase inhibitor (Fig. 9). In the absence of IBMX, muscles contained $3.0 \pm 0.2 \mathrm{pmol}$ of cyclic AMP/ mg of protein (SEM, $n=21$ ) and 30 -fold less cyclic GMP $(0.10 \pm 0.01 \mathrm{pmol} / \mathrm{mg}$ of protein, SEM, $n=24)$. Adding IBMX causes a 1.7-fold increase in cyclic AMP and a 6.4-fold increase in cyclic GMP.

In the presence of IBMX, $10^{-6} \mathrm{M}$ serotonin increases cyclic AMP 6.5-fold, whereas in the absence of IBMX the increase is smaller (1.8-fold). Octopamine also elevates cyclic AMP but is considerably less effective; even at $10^{-4} \mathrm{M}$, octopamine evokes only a 2.2 -fold increase in the presence and a 1.3-fold increase in the absence of IBMX. A complete dose response relationship for the effect of serotonin and octopamine on cyclic AMP levels has been described in a previous study from this laboratory (Battelle and Kravitz, 1978). In contrast to the amines, proctolin, with or without IBMX, causes no detectable change in cyclic AMP even at $10^{-6} \mathrm{M}$, a concentration $10^{4}$-fold greater than the threshold for its physiological effects.

Unlike cyclic AMP, cyclic GMP levels are not detectably altered by either $10^{-6} \mathrm{M}$ serotonin, $10^{-4} \mathrm{M}$ octopamine, or $10^{-6} \mathrm{M}$ proctolin in the presence or absence of IBMX (Fig. $9 b$ ).

Pharmacological manipulations of cyclic nucleotide levels. To test the hypothesis that cyclic nucleotides induce phosphorylation of the 29,000-dalton protein in the intact opener muscle, we tried to alter cyclic nucleotide levels with agents that are effective in other systems. One of these agents, forskolin, is reported to activate adenylate cyclase (Seamon et al., 1981). Forskolin evokes very large increases in cyclic AMP in the opener muscle (up to 50-fold), even in the absence of IBMX. A time course of the effects of forskolin $\left(10^{-4} \mathrm{M}\right)$ on cyclic AMP is shown in Figure 10a. Within 15 min, a 10 -fold increase occurs and cyclic AMP levels continue to rise for at least $2 \mathrm{hr}$. A dose response relationship for forskolin is shown in Figure $11 a$. Up to $2 \%$ ethanol was added to the highest concentration of forskolin to solubilize it, but this concentration of ethanol alone had no effect on cyclic nucleotide levels. Forskolin also increases cyclic GMP in the opener muscle (Figs. $10 b$ and $11 b$ ), although this increase is smaller than that observed for cyclic AMP. A 60-min exposure to $10^{-4} \mathrm{M}$ forskolin, for example, causes a 10 -fold rise in cyclic GMP, whereas the same conditions evoke a 54-fold rise in cyclic AMP (Fig. 10, $a$ and $b$ ).

Another potent activator of adenylate cyclase is cholera toxin (see review by Gill, 1977). Applied to intact lobster muscles, however, cholera toxin appears not to affect levels of cyclic AMP or cyclic GMP. Concentrations as high as $20 \mu \mathrm{g} / \mathrm{ml}$ were tried for periods of $30 \mathrm{~min}$ to $4 \mathrm{hr}$, either at $12^{\circ} \mathrm{C}$ (the normal incubation temperature) or $23^{\circ} \mathrm{C}$, with or without IBMX. Since the toxin 


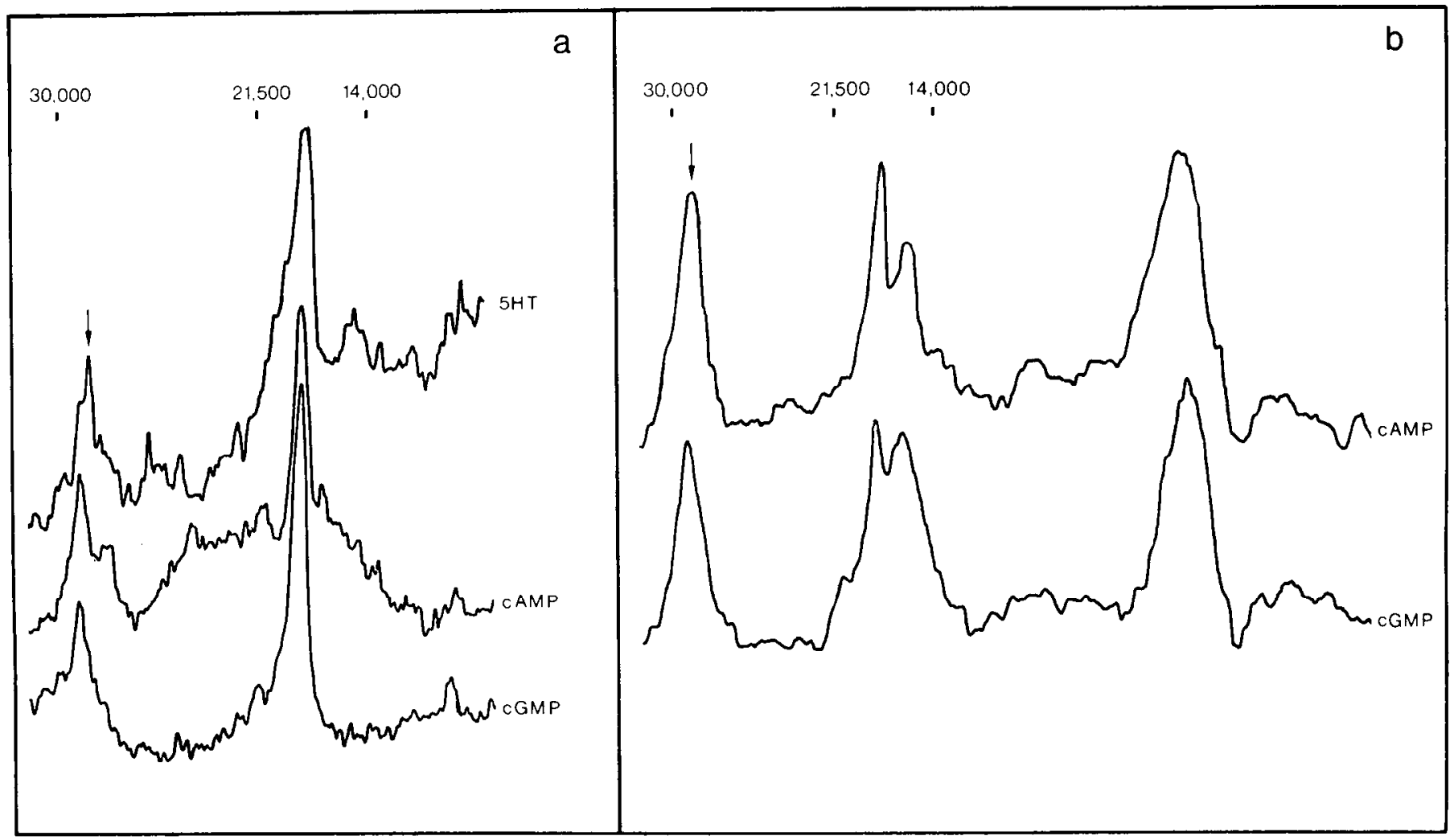

Figure 7. Densitometric scans of labeled products following limited proteolysis of the 29,000-dalton protein. $a$, Fragments generated by $0.5 \mathrm{mg} / \mathrm{ml}$ of trypsin. Phosphorylated 29,000 -dalton protein was obtained from intact preparations treated with $10^{-6} \mathrm{M}$ serotonin $(5 H T)$ or from homogenates treated with $100 \mu \mathrm{M}$ cyclic AMP (cAMP) or cyclic GMP $(c G M P)$. b, Fragments generated by $1 \mathrm{mg} / \mathrm{ml}$ of $S$. aureus V8 protease. Phosphorylated 29,000-dalton protein was obtained from high-speed supernatant fractions of homogenates treated with $100 \mu \mathrm{M}$ cyclic AMP (cAMP) or cyclic GMP (cGMP). Because the high-speed supernatant fraction is enriched for the 29,000 -dalton protein (see the text), conditions could be used in which the protein is digested more completely than in $a$, and more radioactivity could be detected in these products. The positions of molecular weight standards are shown for each experiment, and the location of the undigested 29,000 -dalton protein is indicated by the arrow. No fragments were detected in digests of this region from samples that had not been exposed to serotonin or cyclic nucleotides (data not shown).

binds to ganglioside $\mathrm{G}_{\mathrm{M} 1}$ on cell surfaces (Gill, 1977), the failure of the toxin to act on the intact opener muscle may be due to the reported lack of gangliosides in invertebrate nervous tissue (Honegger and Freyvogel, 1963; Komai et al., 1971).

RMI 12,330A has been used as an inhibitor of adenylate cyclase (Guellaen et al., 1977; Wiech et al., 1978; Ilundain and Naftalin, 1979). When applied to the opener muscle for $2 \mathrm{hr}$ in the presence of IBMX, $1 \mathrm{mM}$ RMI $12,330 \mathrm{~A}$ in $1 \%$ ethanol causes a slight decrease in the basal level of cyclic AMP and markedly reduces the increase in cyclic AMP caused by a subsequent 15-min exposure to $10^{-6} \mathrm{M}$ serotonin (Fig. 12). A higher concentration of RMI $12,330 \mathrm{~A}$ (3.1 mM) completely blocks the serotonin-induced increase, whereas a low concentration $(0.25 \mathrm{mM})$ is not effective.

RMI 12,330A has been reported to have side effects on enzymes other than adenylate cyclase (Guellaen et al., 1978; Roberts and Taylor, 1978), including the inhibition of phosphodiesterase (Hunt and Evans, 1980). Although no increases in cyclic nucleotides that might be attributed to an inhibition of a phosphodiesterase were detected, RMI 12,330A did decrease cyclic GMP by $37 \pm$
$18 \%(\mathrm{SD}, n=4)$. It is possible, therefore, that this agent inhibits guanylate cyclase as well as adenylate cyclase in this system. Other side effects of RMI 12,330A are reported below.

Pharmacological manipulations of phosphorylation in intact preparations. Agents that alter cyclic nucleotide metabolism, and others that influence sarcoplasmic calcium levels, were examined for effects on protein phosphorylation in intact nerve-muscle preparations to see if these effects are consistent with the observation in homogenates that cyclic AMP and cyclic GMP, but not calcium, lead to phosphorylation of the 29,000-dalton protein.

Substances that increase cyclic AMP and cyclic GMP cause the phosphorylation. Thus forskolin, at concentrations as low as $30 \mu \mathrm{M}$, produces phosphorylation of a protein that co-migrates with the serotonin-induced phosphorylation (see Fig. 13) and has been shown by proteolytic digestion $(5 \mu \mathrm{g} / \mathrm{ml}$ or $50 \mu \mathrm{g} / \mathrm{ml}$ of $S$. aureus V8 protease and $50 \mu \mathrm{g} / \mathrm{ml}$ of trypsin, data not shown) to be the same protein. Similarly, IBMX has effects on the 29,000-dalton protein that are parallel to its effects on cyclic nucleotides. As shown in Figure 5, IBMX elicits 


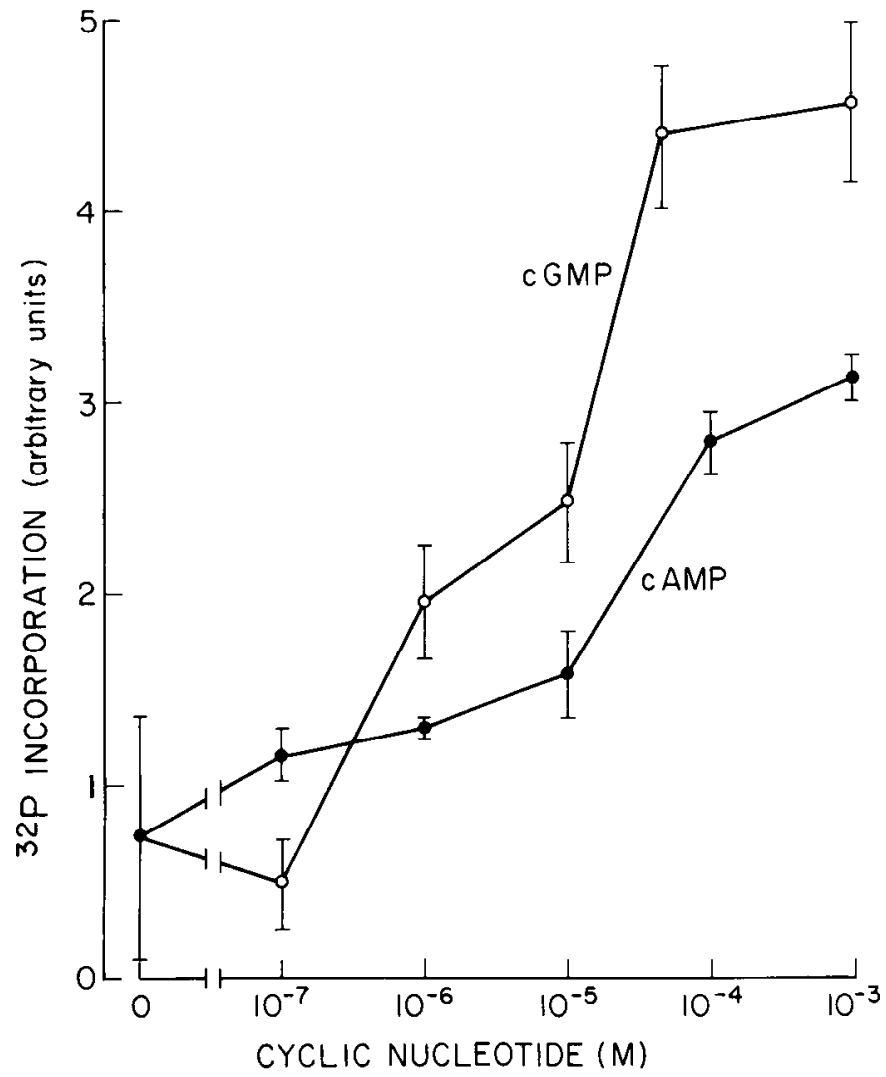

Figure 8. Phosphorylation of the 29,000 -dalton protein in homogenates as a function of cyclic nucleotide concentration. The ordinate, in arbitrary units, gives the amount of phosphorylation of the 29,000-dalton protein, measured and normalized as described under "Materials and Methods." Samples were treated with cyclic AMP (O) or cyclic GMP $(O)$ as indicated. Each point is the average of two determinations; the values of the individual determinations are given by the error bar.

the phosphorylation and potentiates the effect of octopamine. Unlike forskolin and IBMX, cholera toxin does not appear to cause the phosphorylation. This is consistent with the failure of cholera toxin to increase cyclic AMP (see above).

8-Br-cyclic AMP and 8-Br-cyclic GMP also evoke phosphorylation of the 29,000-dalton protein (Fig. 13). Just as cyclic GMP was more effective than cyclic AMP in causing the phosphorylation in a homogenate, $8-\mathrm{Br}$ cyclic GMP is more potent than 8-Br-cyclic AMP when applied to intact preparations. A 15 -min exposure to 1 mM 8-Br-cyclic GMP was sufficient to produce the phosphorylation, whereas $1 \mathrm{mM} 8$-Br-cyclic AMP was only effective after $60 \mathrm{~min}$. A 10 -fold higher concentration of 8-Br-cyclic AMP (10 mM) was necessary to approximate the effect of $1 \mathrm{mM} 8$-Br-cyclic GMP when both agents were applied for $60 \mathrm{~min}$. This may be because $8-\mathrm{Br}$-cyclic GMP enters the cell more easily or because $8-\mathrm{Br}$-cyclic GMP is more effective once inside.

The same concentration of RMI 12,330A that inhibits the serotonin-induced increase in cyclic AMP (Fig. 12) also inhibits the serotonin-induced phosphorylation (1 $\mathrm{mM}$ for $2 \mathrm{hr}$; Fig. 13). Unfortunately, however, this drug causes a general decrease in the phosphorylation of all proteins (Fig. 13). When higher concentrations of RMI $12,330 \mathrm{~A}$ were used or when the drug was applied for longer periods of time, the reduction in overall phosphorylation was more pronounced. One millimolar RMI $12,330 \mathrm{~A}$ was selected as the best concentration because it almost completely blocks phosphorylation of the 29,000-dalton protein and has much less effect on other bands on the gel.

Substances that affect sarcoplasmic $\mathrm{Ca}^{2+}$ levels do not influence the phosphorylation. Thus $\mathrm{Mn}^{2+}(5 \mathrm{mM})$, a $\mathrm{Ca}^{2+}$ channel blocker that inhibits the hormone-evoked contracture (Kravitz et al., 1980), has no effect on the serotonin-induced phosphorylation (Fig. 13). Furthermore, caffeine $(2 \mathrm{mM})$ or high $\mathrm{KCl}(24 \mathrm{mM})$ which evoke contractures equal to or greater than those of serotonin, presumably by increasing intracellular $\mathrm{Ca}^{2+}$ levels, do not cause the phosphorylation (Fig. 13).

Fractionation of homogenates. Homogenates were fractionated by two centrifugations $(600 \times g$ and $96,000 \times g$; see "Materials and Methods"). The effect of cyclic AMP on phosphorylation of the 29,000-dalton protein in each fraction is shown in Figure 14. The effect of cyclic GMP on the phosphorylation (not shown) is parallel to that of cyclic AMP.

The pellet of the $600 \times g$ centrifugation, which is likely to contain cell debris and myofibrils, shows very little
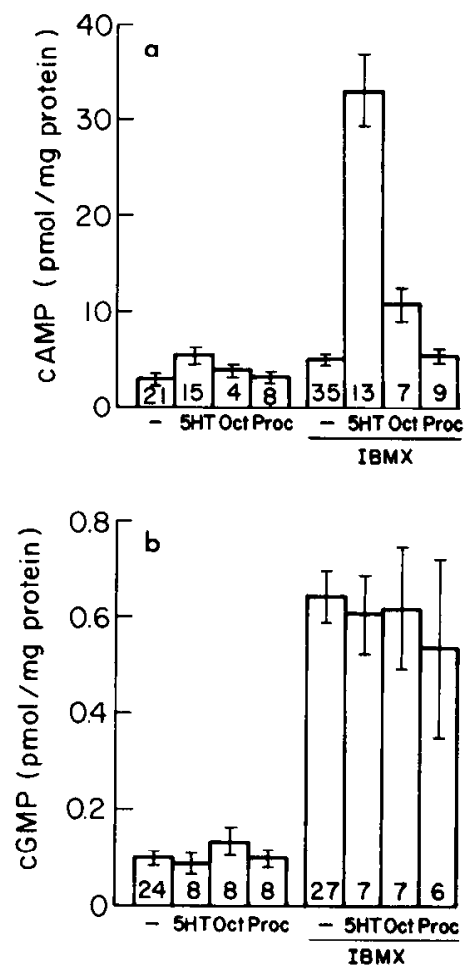

Figure 9. The effects of serotonin, octopamine, and proctolin on cyclic AMP $(a)$ or cyclic GMP $(b)$ in the opener muscle. Muscles were incubated for $4 \mathrm{hr}$ in the presence or absence of $0.5 \mathrm{mM}$ IBMX as indicated. Muscles either received no addition (-) or were given $10^{-6} \mathrm{M}$ serotonin $(5 H T), 10^{-4} \mathrm{M}$ octopamine (Oct), or $10^{-6} \mathrm{M}$ proctolin (Proc) for the final $15 \mathrm{~min}$ of the incubation. Cyclic nucleotides were measured and normalized to protein as described under "Materials and Methods." For each condition the mean $\pm S E M$ is indicated, and the number of determinations is shown for each bar. 


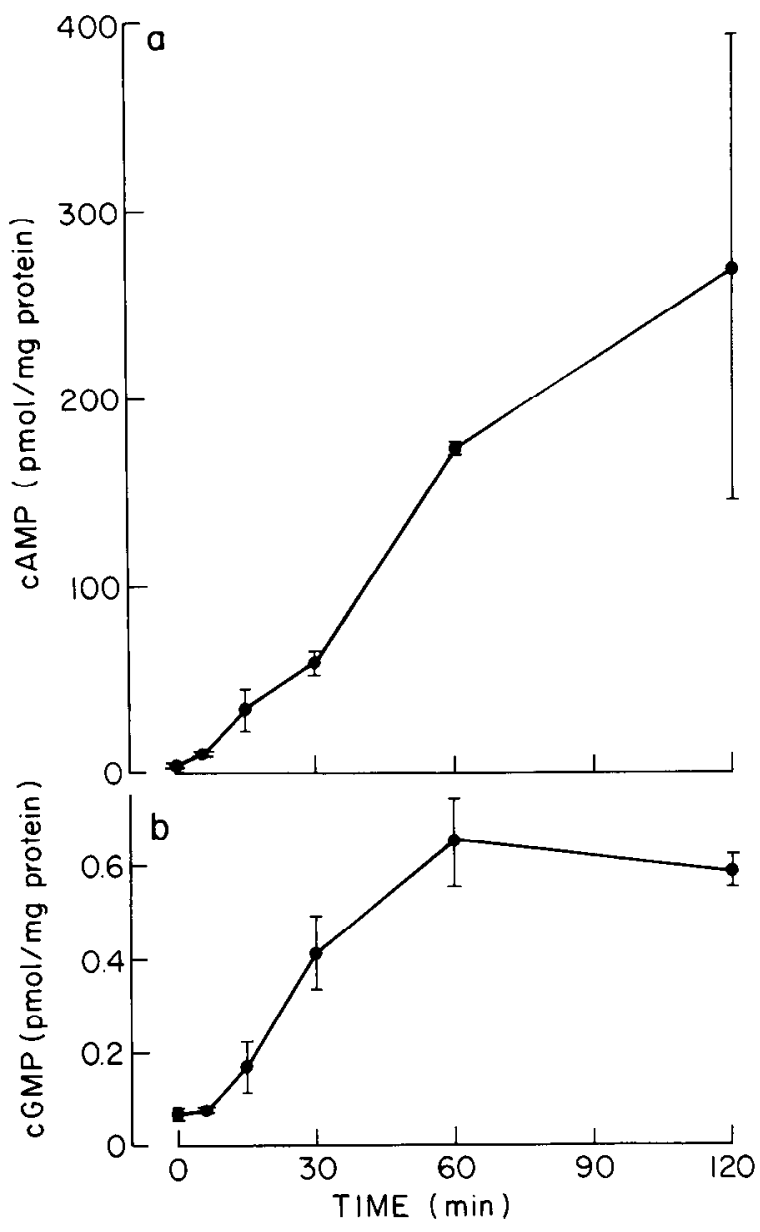

Figure 10. The time course of the forskolin-induced increase in cyclic nucleotides. Opener muscles were incubated for a total of $3 \mathrm{hr}$ (in the absence of IBMX). Forskolin $(100 \mu \mathrm{M})$ was present for the final period of the incubation, and the duration of this period is indicated on the abscissa. Cyclic AMP $(a)$ and cyclic GMP (b) were measured and normalized to protein as described under "Materials and Methods." Two determinations were made for each time point, and the values of the individual muscles are indicated by the extremes of the error bars. Note that the scales of the ordinates differ in the two halves of the figure. Although $0.67 \%$ ethanol was used to solubilize the forskolin, this concentration of ethanol does not affect cyclic nucleotide levels.

phosphorylation of the 29,000-dalton protein in response to cyclic nucleotides (Fig. 14, lanes 3 and 4 ). In the supernatant fraction of this centrifugation, the phosphorylation is correspondingly enhanced (not shown). Further fractionation of the supernatant by centrifugation at $96,000 \times g$ yields a particulate fraction in which the phosphorylation of the 29,000-dalton protein is barely detectable and a soluble fraction highly enriched for the phosphorylated protein (Fig. 14, lanes 5 to 8 ).

The lack of phosphorylation of the 29,000-dalton protein in the $96,000 \times g$ pellet could be due to the absence of the protein itself or the absence of the kinase or some other factor required for the reaction. To distinguish these two possibilities, the reaction was performed on the supernatant fraction of the $600 \times g$ centrifugation and this fraction was subsequently centrifuged at 96,000 $\times g$. The pellet of this centrifugation still contained only a trace of the phosphorylated 29,000-dalton protein (Fig. 14 , lanes 9 to 12 ). The 29,000-dalton protein and the kinase or kinases that phosphorylate it, therefore, appear to be soluble proteins, although we cannot exclude the possibility that a small amount of the 29,000-dalton protein is membrane-bound.

Phosphorylation in other tissues. The effects of cyclic AMP and cyclic GMP on phosphorylation were examined in homogenates of other lobster tissues to determine the distribution of the 29,000-dalton protein (Fig. 15). A protein that co-migrates with the 29,000 -dalton protein from the dactyl opener muscle and whose phosphorylation is greatly increased by cyclic AMP and cyclic GMP was found in three other muscles (the dactyl opener of the crusher claw, the dactyl closer of the walking leg, and the meropodite flexor of the walking leg) and in two nonmuscle tissues. In the gill, as in the opener muscle,

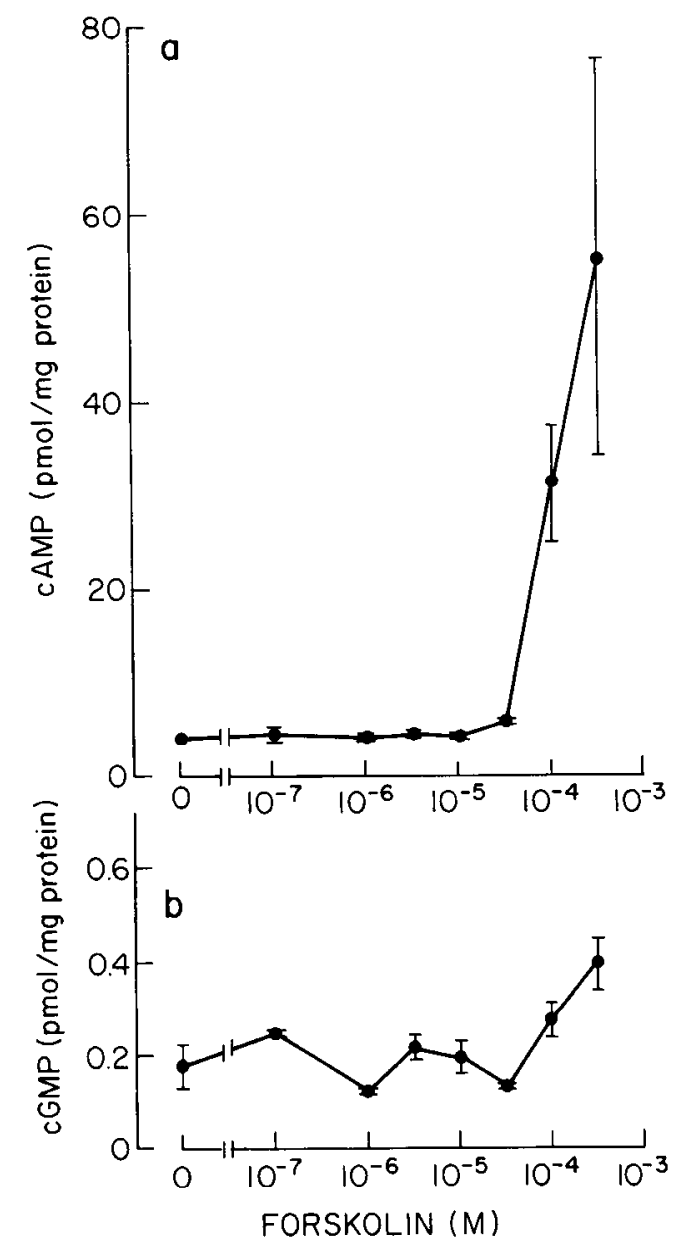

Figure 11. The dose response relationship of the forskolininduced increase in cyclic nucleotides. Forskolin was present for $15 \mathrm{~min}$ at the end of a 4-hr incubation (in the absence of IBMX). Cyclic AMP $(a)$ and cylic GMP $(b)$ were measured and normalized to protein as described under "Materials and Methods." Two determinations were made for each concentration, and the values of the individual muscles are indicated by the extremes of the error bars. Note that the scales of the ordinates differ in the two halves of the figure. To solubilize the forskolin, ethanol was added (up to $2 \%$ for the highest concentration of forskolin), but ethanol alone did not increase either cyclic nucleotide. 


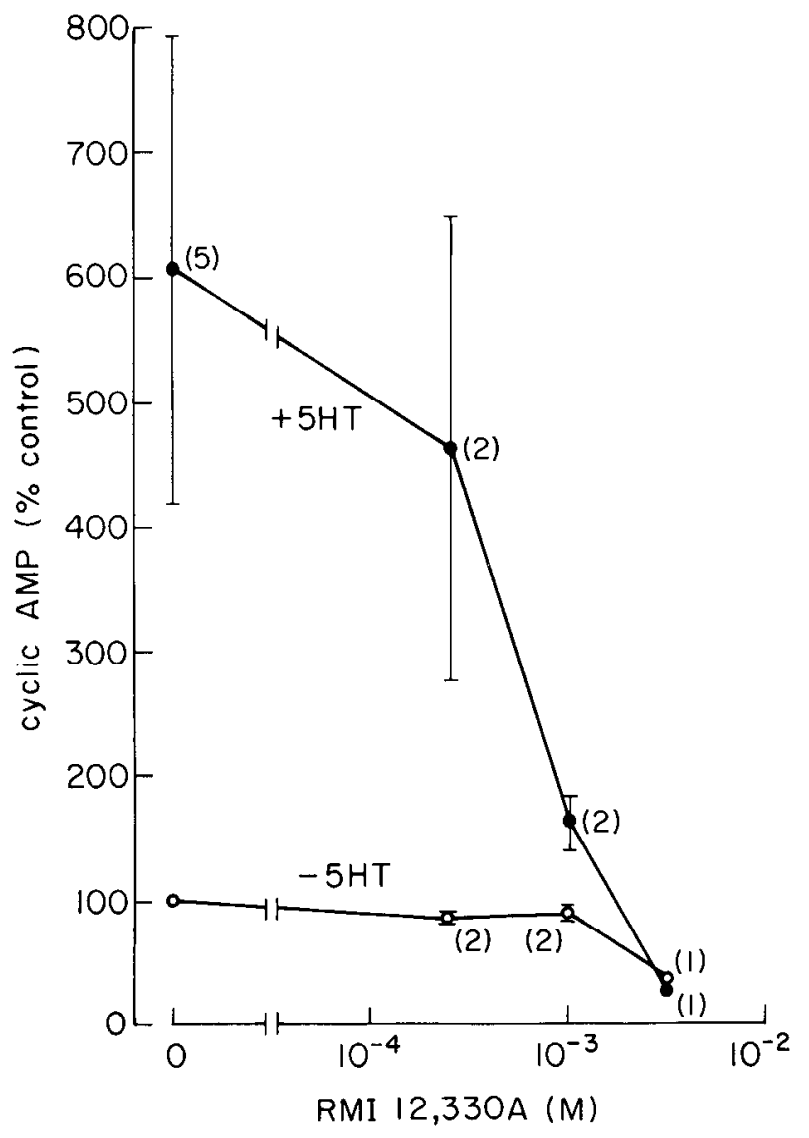

Figure 12. The effect of RMI 12,330A on cyclic AMP levels in the presence and absence of serotonin $(5 H T)$. Intact preparations were incubated for $2 \mathrm{hr}$ with $0.5 \mathrm{mM}$ IBMX and various concentrations of RMI 12,330A as indicated in the figure. For the last $15 \mathrm{~min}$ of the incubation, preparations received either $10^{-6} \mathrm{M}$ serotonin (O) or no addition (O). For each of these preparations, another muscle from the same lobster was incubated in IBMX but in the absence of RMI 12,330A and serotonin. The cyclic AMP levels in treated muscles are expressed as a percentage of that in the control. (The cyclic AMP level in the absence of serotonin and RMI 12,330A is, therefore, defined as $100 \%$ in the figure). The number of determinations at each concentration of RMI $12,330 \mathrm{~A}$ is given in parentheses; the error bars show either the standard error of the mean or, in the case of duplicate determinations, the actual values for the two preparations. The highest concentration of RMI $12,330 \mathrm{~A}$ was kept in solution with $5 \%$ dimethyl sulfoxide. Lower concentrations were solubilized with ethanol (up to $1 \%$ ). Neither of these solvents by themselves inhibited the serotonininduced increase in cyclic AMP (data not shown).

the protein was enriched in a $96,000 \times g$ soluble fraction. A 29,000-dalton phosphoprotein was also found in a soluble fraction prepared from the first three thoracic ganglia and the connectives that join them. This phosphorylation could not be detected in an unfractionated homogenate of these ganglia. We have not yet compared the 29,000-dalton proteins from these tissues by an analysis of their proteolytic fragments.

Ovary and heart tissue also contain a phosphoprotein that co-migrates with the 29,000 -dalton protein. In these tissues, however, the extent of phosphorylation was not affected by cyclic AMP or cyclic GMP. We do not know whether our incubation conditions were inappropriate for observing an effect of cyclic nucleotides in heart and ovary or whether the protein from these tissues is different from that of the opener muscle.

\section{Discussion}

In examining the biochemical effects of serotonin on the lobster dactyl opener muscle, we found that serotonin causes phosphorylation of a 29,000-dalton protein in intact tissues labeled with ${ }^{32} \mathrm{P}_{\mathrm{i}}$. Although this was the only apparent change, we would not have detected alterations in phosphoproteins that (1) were present in very small quantities, (2) co-migrated with other heavily labeled proteins, (3) were only slightly affected by serotonin, or (4) were exceptionally labile.

A cyclic nucleotide, probably cyclic AMP, appears to mediate the serotonin-induced phosphorylation. (1) Phosphorylation of this protein occurs when cyclic AMP or cyclic GMP is added to homogenates of the tissue. (2) In intact preparations, phosphorylation of an apparently identical protein is caused by agents that raise cyclic nucleotide levels (forskolin, IBMX, 8-Br-cyclic AMP, and 8-Br-cyclic GMP). (3) The effectiveness of hormones in evoking phosphorylation correlates well with their ability to increase cyclic AMP. Thus, serotonin produces a large increase in cyclic AMP and is a potent agonist of the phosphorylation, whereas octopamine, a weaker agonist of the phosphorylation, elicits a smaller increase in cyclic AMP. Proctolin, a third hormone with physiological effects on the muscle, does not cause the phosphorylation and does not alter cyclic AMP levels in these muscles. (4) An agent that potentiates hormoneinduced increases in cyclic AMP (IBMX) also augments the phosphorylation, whereas a substance that inhibits the change in cyclic AMP (RMI 12,330A) inhibits the phosphorylation.

$\mathrm{Ca}^{2+}$ is probably not the second messenger for the hormone-induced phosphorylation. In intact muscles, increased sarcoplasmic $\mathrm{Ca}^{2+}$ does not result in the phosphorylation, and $\mathrm{Mn}^{2+}$, a $\mathrm{Ca}^{2+}$-channel blocker, does not prevent it. Furthermore, adding $\mathrm{Ca}^{2+}$ to a homogenate does not lead to the phosphorylation.

Two cyclic nucleotide-dependent protein kinases that might catalyze the phosphorylation have been partially purified from lobster muscle (Kuo and Greengard, 1970). One of these enzymes is preferentially activated by cyclic AMP, the other by cyclic GMP. The apparent $K_{a}$ 's for activation of these enzymes, and of cyclic nucleotidedependent kinases from other tissues, are in the range of 5 to $100 \mathrm{nM}$ (Nimmo and Cohen, 1977; Kuo et al., 1978). In our homogenates, however, higher concentrations of cyclic AMP and cyclic GMP are necessary to induce phosphorylation (Fig. 8). Furthermore, as calculated from measurements of cyclic nucleotides (Fig. 9) and the intracellular volume of our preparations (see "Materials and Methods"), the concentration of cyclic AMP in a serotonin-treated muscle is approximately $2 \mu \mathrm{M}$ and the concentration of cyclic GMP is about $30 \mathrm{nM}$. Although these concentrations could be exceeded in particular subcellular pools, they are not sufficient to produce phosphorylation in homogenates of the opener muscle (Fig. 8). A possible explanation of these discrepancies is that 

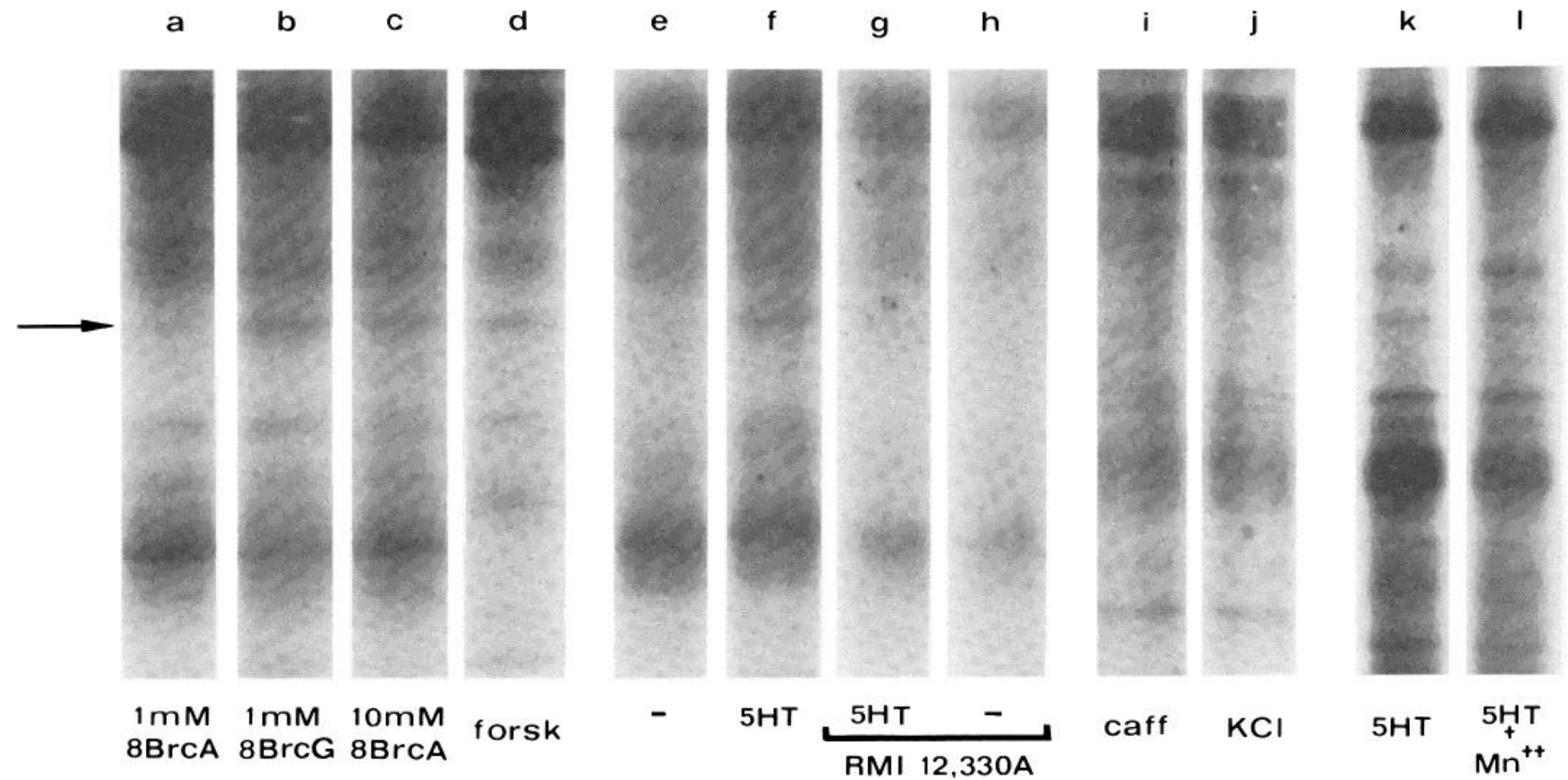

Figure 13. The effect of agents that alter sarcoplasmic cyclic nucleotide and $\mathrm{Ca}^{2+}$ levels on phosphorylation of the 29,000 dalton protein. All muscles were incubated for a total of $4 \mathrm{hr}$ in saline containing ${ }^{32} \mathrm{P}_{\mathrm{i}}$ and received the following additions during the last part of the incubation: $a, 1 \mathrm{~mm} \mathrm{8-Br-cyclic} \mathrm{AMP} \mathrm{for} 60 \mathrm{~min} ; b, 1 \mathrm{~mm} 8$-Br-cyclic GMP for $60 \mathrm{~min} ; c, 10 \mathrm{~mm} 8$-Br-cyclic AMP for $60 \mathrm{~min} ; d, 30 \mu \mathrm{M}$ forskolin $+0.2 \%$ ethanol for $15 \mathrm{~min} ; e, 1 \%$ ethanol for $2 \mathrm{hr} ; f, 1 \%$ ethanol for $2 \mathrm{hr}$ and $10^{-6} \mathrm{M}$ serotonin for the final $15 \mathrm{~min} ; \mathrm{g}, 1 \mathrm{mM}$ RMI $12,330 \mathrm{~A}+1 \%$ ethanol for $2 \mathrm{hr}$ and $10^{-6} \mathrm{M}$ serotonin for the final $15 \mathrm{~min}$; $h$, $1 \mathrm{mM}$ RMI $12,330 \mathrm{~A}+1 \%$ ethanol for $2 \mathrm{hr} ; i, 2 \mathrm{mM}$ caffeine for $15 \mathrm{~min} ; j, 24 \mathrm{mM} \mathrm{KCl}$ (raised from $16 \mathrm{~mm}$ ) for $15 \mathrm{~min} ; k, 10^{-6} \mathrm{M}$ serotonin for $15 \mathrm{~min} ; l, 10 \mathrm{mM} \mathrm{MnCl}_{2}$ for the final $20 \mathrm{~min}$ and $10^{-6} \mathrm{M}$ serotonin for the final 15 min. The lanes in the figure are from several different experiments in which the distribution of labeled proteins varies somewhat. The arrow marks the position of the 29,000 -dalton protein. Ethanol was required in some experiments to solubilize the forskolin or the RMI $12,330 \mathrm{~A}$, but it had no effect on the phosphorylation. RMI $12,330 \mathrm{~A}$, on the other hand, consistently reduced phosphorylation of all proteins in the gel (see "Results").

phosphodiesterases in the homogenate are degrading cyclic AMP and cyclic GMP, and, therefore, the concentrations of cyclic nucleotides actually present (and hence the true thresholds for phosphorylation) are lower than indicated. It is also possible that the homogenization conditions were not optimal for the kinases, which are particularly sensitive to the concentrations of divalent cations (Miyamoto et al., 1969; Kuo et al., 1978).

The above considerations make it difficult to speculate on the nature of the kinase or kinases that phosphorylate the 29,000-dalton protein. Cyclic GMP, however, appears to be a more potent agonist of the phosphorylation than cyclic AMP in homogenates. This may not be an artifact of the homogenization conditions since, in intact tissues, 8-Br-cyclic GMP is more effective than 8-Br-cyclic AMP. One possibility is that both cyclic nucleotides act through a single kinase that prefers cyclic GMP, like that described by Kuo and Greengard (1970). Alternatively, cyclic AMP and cyclic GMP may phosphorylate the 29,000-dalton protein through separate kinases. If so, the kinases must phosphorylate the same or nearby sites, since analysis of proteolytic fragments of the protein has not yet revealed a difference between cyclic AMP-stimulated and cyclic GMP-stimulated phosphorylations.
Cyclic GMP is not likely to mediate the serotonininduced phosphorylation in intact preparations, because we found no detectable elevation of cyclic GMP $\mathrm{v}$ hen serotonin was applied. It remains possible, however, that serotonin increases cyclic GMP in a small subcellular compartment and that this undetectable increase leads to the phosphorylation. Agents that selectively blocked or potentiated changes in either cyclic AMP or cyclic GMP might have enabled us to rule out this possibility. The agents we have tested (IBMX and RMI 12,330A), however, affect both cyclic nucleotides.

The significance of the cyclic GMP-induced phosphorylation remains uncertain, since none of the hormones that we tested cause a measurable increase in cyclic GMP. It is possible that some as yet unidentified agent can increase cyclic GMP in these tissues and thereby cause the phosphorylation of the same protein that is phosphorylated by serotonin through cyclic AMP. Several examples of convergence on a single phosphoprotein by two pathways employing different second messengers provide precedent for this idea (Cohen, 1982).

The function of the serotonin-induced phosphorylation is not yet known. In other systems it has been suggested that serotonin acts by phosphorylating a membrane ion channel (Greengard, 1976; de Peyer et al., 


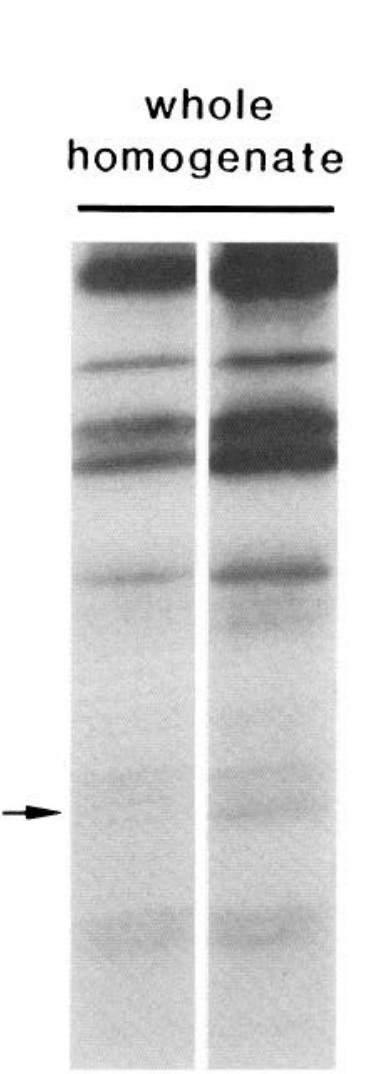

- CAMP
$600 \times \mathrm{g}$

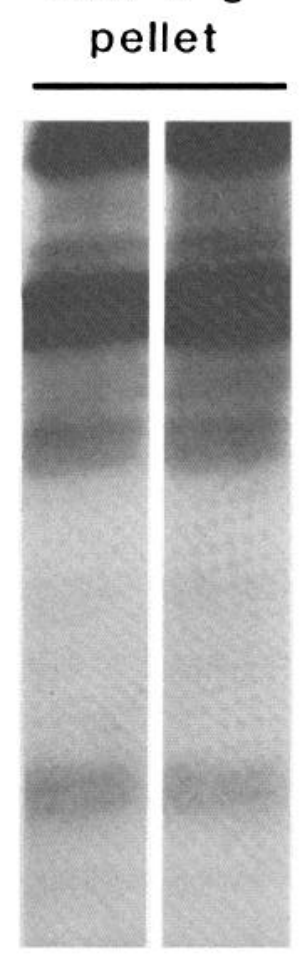

cAMP

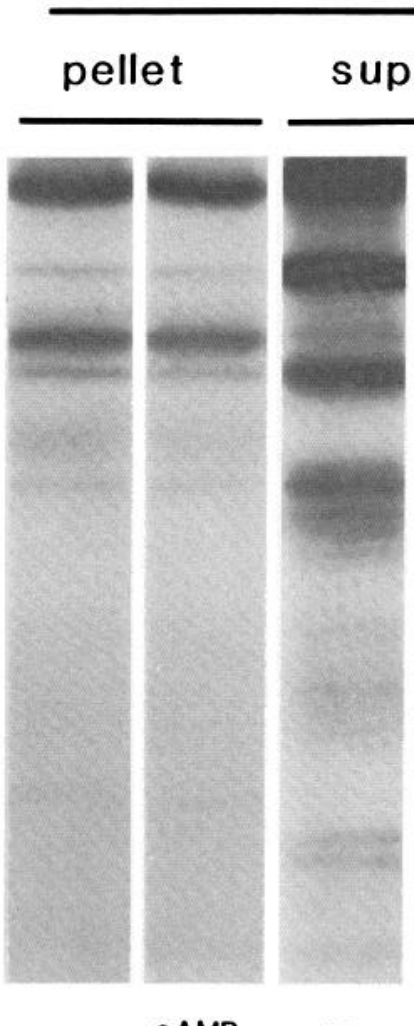

CAMP
$96,000 \times$ $\mathrm{xg}$

Figure 14. Phosphorylation of the 29,000-dalton protein in fractions obtained from homogenates by centrifugation. A homogenate of the opener muscle preparation (lanes 1 and 2) was centrifuged at $600 \times g$, yielding a pellet (lanes 3 and 4 ) and a supernatant fraction. The supernatant fraction was subsequently centrifuged at $96,000 \times g$, yielding a pellet (lanes $5,6,9$, and 10 ) and a supernatant fraction (lanes $7,8,11$, and 12). Lanes 9 to 12 (*) were phosphorylated before centrifugation at $96,000 \times$ $g$, whereas lanes 5 to 8 were phosphorylated after centrifugation. Fractions were tested in the absence $(-)$ or presence $(c A M P)$ of $100 \mu \mathrm{M}$ cyclic AMP, as described under "Materials and Methods." The arrow marks the position of the 29,000-dalton protein."

1982; Paris et al., 1982). Since the 29,000-dalton protein is soluble, it is not likely to be a channel, although it might regulate the activity of a channel. In the nervemuscle preparation where we first detected the phosphorylated protein, serotonin causes increased release of transmitter from nerve terminals and increased tension in muscle fibers. However, an apparently identical protein also appears to be phosphorylated in gills. This suggests that the phosphorylation participates in some aspects of metabolism common to several types of cells, rather than in an activity unique to nerve or muscle. Nevertheless, phosphorylation of the 29,000 -dalton protein could still be related to the serotonin-induced changes in nerve and muscle physiology. For example, if the protein were part of a general mechanism for regulating intracellular $\mathrm{Ca}^{2+}$ levels, then phosphorylationinduced changes in $\mathrm{Ca}^{2+}$ concentration could affect transmitter release in nerve terminals, tension in muscle fibers, and some as yet unknown processes in gills.

The slow time course and low threshold of the serotonin-induced phosphorylation are compatible with both the pre- and postsynaptic effects of serotonin. In other respects, however, the actions of serotonin, octopamine, and proctolin on phosphorylation do not correlate well with their postsynaptic effects. Because the contractures produced by the latter two are indistinguishable from those produced by serotonin, the three hormones may act through a common mechanism. Proctolin, however, fails to cause the phosphorylation even at concentrations $10^{6}$-fold above its threshold for causing contracture. Octopamine, under certain conditions, causes what appears to be the same phosphorylation as serotonin. The significance of this event, however, is not clear; the octopamine-induced phosphorylation requires either (1) concentrations of octopamine 100 -fold greater than the threshold for its physiological actions or (2) the presence of IBMX, which is not a requirement for the physiological effects. Therefore, if the phosphorylation is involved in producing contractures, it is in a pathway restricted to serotonin and, perhaps, octopamine.

Might the serotonin-enhanced release of transmitter involve the 29,000-dalton protein? Presynaptic modulation, like the phosphorylation, is caused by serotonin but not by proctolin. Octopamine, which is only a weak agonist of the phosphorylation, is much less effective than serotonin in enhancing release (Kravitz et. al., 1980; 


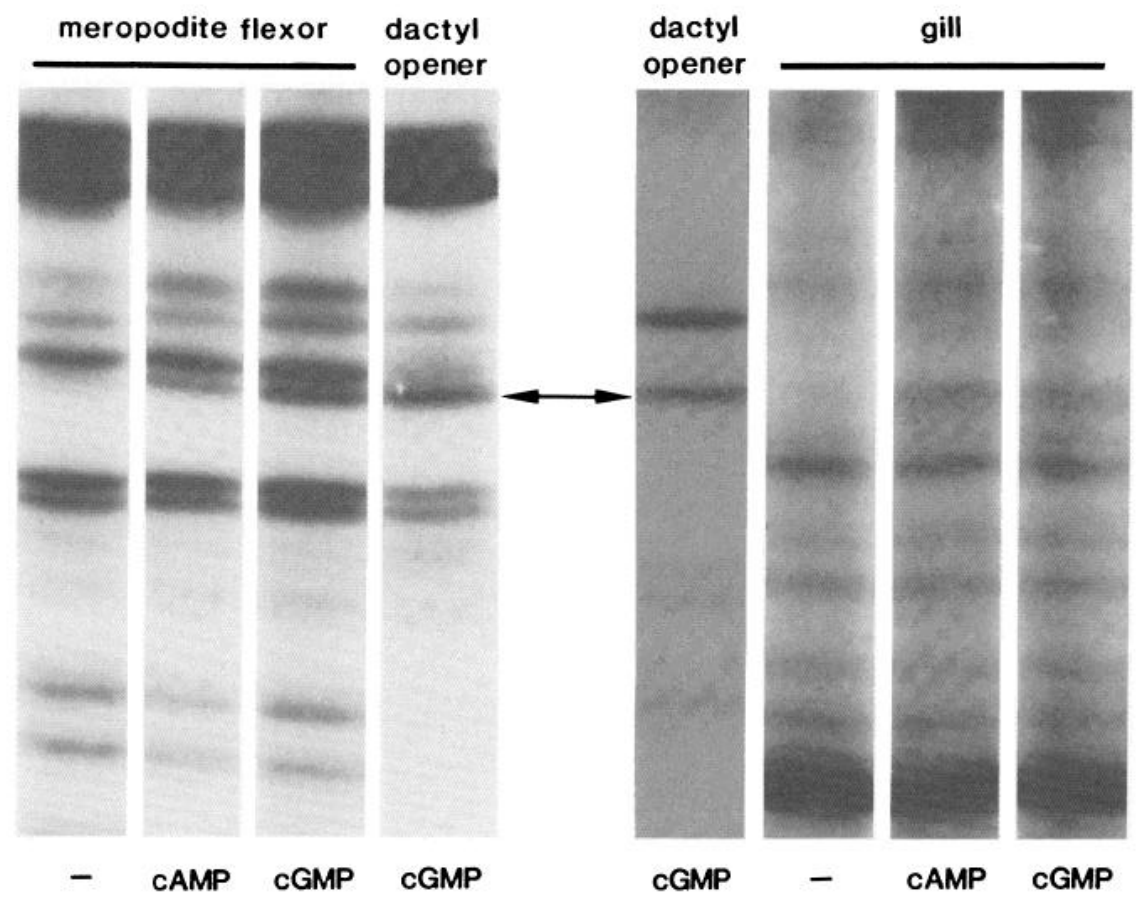

Figure 15. Cyclic nucleotides cause phosphorylation of a 29,000-dalton protein in several tissues from the lobster. The meropodite flexor of a walking leg and a branchia from the gill were dissected and homogenized under the same conditions as were used for the dactyl opener muscle. A soluble fraction was prepared from the gill by centrifugations at $600 \times \mathrm{g}$ for $40 \mathrm{~min}$ and $96,000 \times \mathrm{g}$ for $15 \mathrm{~min}$ (see "Materials and Methods"). For comparison, homogenates of an opener muscle are also shown: a whole homogenate is paired with the meropodite flexor, and a soluble fraction is paired with the gill. Protein phosphorylation was assayed in the absence of cyclic nucleotides (-) and in the presence of $100 \mu \mathrm{M}$ cyclic AMP $(c A M P)$ or $100 \mu \mathrm{M}$ cyclic GMP $(c G M P)$. The position of the 29,000 -dalton protein is marked by the arrows.

for related work in crayfish see Breen and Atwood, 1983, and Fischer and Florey, 1983). Thus, although more information is needed, the phosphorylation correlates better with presynaptic than postsynaptic actions.

A final possibility is that the phosphorylation is involved in some unknown action of serotonin not directly related to muscle contraction or transmitter release. The effect of epinephrine on vertebrate neuromuscular preparations provides precedent for a single hormone having diverse actions. In addition to modulatory effects on transmitter release and muscle tension (Krnjevic and Miledi, 1958; Bowman and Zaimas, 1958; Jenkinson et al., 1968; Kuba, 1970), epinephrine, through cyclic AMPmediated protein phosphorylation, also affects aspects of cellular metabolism such as the synthesis or breakdown of glycogen and lipid (Nimmo and Cohen, 1977). Learning whether the 29,000-dalton protein is involved in such metabolic regulation, or in the neuromodulatory effects of serotonin, must await further experimentation. The demonstration in this paper that forskolin and the 8-Brcyclic nucleotides cause the phosphorylation, while RMI $12,330 \mathrm{~A}$ blocks it, provides opportunities to examine this question. By analyzing the effects of these drugs on the physiology of intact preparations, we hope to establish which of the actions of serotonin involve changes in cyclic AMP and phosphorylation of the 29,000-dalton protein. Studying these biochemical events is a first step toward understanding the mechanism of hormonal modulation at this neuromuscular junction.

\section{References}

Adams, W. B., and I. B. Levitan (1982) Intracellular injection of protein kinase inhibitor blocks the serotonin-induced increase in $\mathrm{K}^{+}$conductance in Aplysia neuron R15. Proc. Natl. Acad. Sci. U. S. A. 79: 3877-3880.

Bárány, M., and K. Bárány (1980) Phosphorylation of the myofibrillar proteins. Annu. Rev. Physiol. 42: 275-292.

Battelle, B. -A., and E. A. Kravitz (1978) Targets of octopamine action in the lobster: Cyclic nucleotide changes and physiological effects in hemolymph, heart, and exoskeletal muscle. J. Pharmacol. Exp. Ther. 205: 438-448.

Bligh, E. G., and W. J. Dyer (1959) A rapid method of total lipid extraction and purification. Can. J. Biochem. Physiol. 37: 911-917.

Bowman, W. C., and E. Zaimas (1958) The effects of adrenaline, noradrenaline and isoprenaline on skeletal muscle contractions in the cat. J. Physiol. (Lond.) 144: 92-107.

Breen, C. A., and H. L. Atwood (1983) Octopamine-a neurohormone with presynaptic activity-dependent effects at crayfish neuromuscular junctions. Nature 303: 716-718.

Castellucci, V. F., E. R. Kandel, J. H. Schwartz, F. D. Wilson, A. C. Nairn, and P. Greengard (1980) Intracellular injection of the catalytic subunit of cyclic AMP-dependent protein kinase simulates facilitation of transmitter release underly- 
ing behavioral sensitization in Aplysia. Proc. Natl. Acad. Sci. U.S. A. 77: 7492-7496.

Castellucci, V. F., A. Nairn, P. Greengard, J. H. Schwartz, and E. R. Kandel (1982) Inhibitor of adenosine $3^{\prime}: 5^{\prime}$-monophosphate-dependent protein kinase blocks presynaptic facilitation in Aplysia. J. Neurosci. 2: 1673-1681.

Cleveland, D. W., S. G. Fischer, M. W. Kirshner, and U. K. Laemmli (1977) Peptide mapping by limited proteolysis in sodium dodecyl sulfate and analysis by gel electrophoresis. $\mathrm{J}$. Biol. Chem. 252: 1102-1106.

Cohen, P. (1982) The role of protein phosphorylation in neural and hormonal control of cellular activity. Nature 296: 613620.

de Peyer, J. E., A. B. Cachelin, I. B. Levitan, and H. Reuter (1982) $\mathrm{Ca}^{2+}$ activated $\mathrm{K}^{+}$conductance in internally perfused snail neurons is enhanced by protein phosphorylation. Proc. Natl. Acad. Sci. U. S. A. 79: 4207-4211.

Dolphin, A. C., and P. Greengard (1981a) Serotonin stimulates phosphorylation of protein I in the facial motor nucleus of rat brain. Nature 289: 76-79.

Dolphin, A. C., and P. Greengard (1981b) Neurotransmitterand neuromodulator-dependent alterations in phosphorylation of protein I in slices of rat facial nucleus. J. Neurosci. 1: 192-203.

Drummond, A. H., J. A. Benson, and I. B. Levitan (1980) Serotonin-induced hyperpolarization of an identified Aplysia neuron is mediated by cyclic AMP. Proc. Natl. Acad. Sci. U. S. A. 77: 5013-5017.

Dudel, J. (1965) Facilitatory effects of 5-hydroxytryptamine on the crayfish neuromuscular junction. Naunyn-Schmiedebergs Arch. Exp. Pathol. Pharmakol. 249: 515-528.

Evans, P. D., B. R. Talamo, and E. A. Kravitz (1975) Octopamine neurons: Morphology, release of octopamine and possible physiolngical role. Brain Res. 90: 340-347.

Fairbanks, G., T. L. Steck, and D. F. H. Wallach (1971) Electrophoretic analysis of the major polypeptides of the human erythrocyte membrane. Biochemistry 10: 2606-2617.

Fischer, L., and E. Florey (1983) Modulation of synaptic transmission and excitation-contraction coupling in the opener muscle of the crayfish, Astacus leptodactylus, by 5-hydroxytryptamine and octopamine. J. Exp. Biol. 102: 187-198.

Florey, E., and E. Florey (1954) Uber die mogliche Bedeutung von Enteramin (5-oxytryptamin) als nervoser Aktimssubstanz bei cephalopoden und dekapoden Crustacean. Z. Naturforsch. 96: 58-68.

Gill, D. M. (1977) Mechanism of action of cholera toxin. Adv. Cyclic Nucleotide Res. 8: 85-118.

Glusman, S., and E. A. Kravitz (1982) The action of serotonin on excitatory nerve terminals in lobster nerve-muscle preparations. J. Physiol. (Lond.) 325: 223-241.

Greengard, P. (1976) Possible role for cyclic nucleotides and phosphorylated membrane proteins in presynaptic actions of neurotransmitters. Nature 260: 101-108.

Greengard, P. (1978) Cyclic Nucleotides, Phosphorylated Proteins, and Neuronal Function, Raven Press, New York.

Grundfest, H., and J. P. Reuben (1961) Neuromuscular synaptic activity in lobster. In Nervous Inhibition, E. Florey, ed., pp. 92-104, Pergamon Press, New York.

Guellaen, G., J. L. Mahu, P. Mavier, P. Berthelot, and J. Ilanoune (1977) RMI $12,330 \mathrm{~A}$, an inhibitor of adenylate cyclase in rat liver. Biochim. Biophys. Acta 484: 465-475.

Guellaen, G., J. L. Mahu, P. Mavier, J. Hanoune, and P. Berthelot (1978) Nonspecific inhibition of some rat liver membrane-bound enzymes by an adenylate cyclase inhibitor, RMI 12,330A. Biochem. Pharmacol. 27: 641-645.

Haymovits, A., and G. A. Scheele (1976) Cellular cyclic nucleotides and enzyme secretion in the pancreatic acinar cell. Proc. Natl. Acad. Sci. U. S. A. 73: 156-160.
Honegger, C. G., and T. A. Freyvogel (1963) I ipide des Zentralnervensystems bei Wirbeltieren und einigen Wirbellosen. Helv. Chim. Acta 46: 2265-2270.

Hunt, N. H., and T. Evans (1980) RMI 12,330A, an inhibitor of cyclic nucleotide phosphodiesterases and adenylate cyclase in kidney preparations. Biochim. Biophys. Acta 613: 499506.

Ilundain, A., and R. J. Naftalin (1979) Role of $\mathrm{Ca}^{++}$-dependent regulator protein in intestinal secretion. Nature 279: 446448.

Jenkinson, D. H., B. A. Stamenovic, and B. D. L. Whitaker (1968) The effect of noradrenalin on the end plate potential in twitch fibers of the frog. J. Physiol. (Lond.) 195: 143-154.

Jennings, K. R., L. K. Kaczmarek, R. M. Hewick, W. J. Dreyer, and F. Strumwasser (1982) Protein phosphorylation during afterdischarge in peptidergic neurons of Aplysia. J. Neurosci. 2: 158-168.

Kaczmarek, L. K., K. R. Jennings, F. Strumwasser, A. C. Nairn, U. Walter, F. D. Wilson, and P. Greengard (1980) Microinjection of protein kinase enhances action potentials of bag call neurons in culture. Proc. Natl. Acad. Sci. U. S. A. 77: 7487-7491.

Kawagoe, R., K. Onodera, and A. Takeuchi (1982) On the quantal release of endogenous glutamate from the crayfish neuromuscular junction. J. Physiol. (Lond.) 322: 529-539.

Kennedy, M. B. (1983) Experimental approaches to understanding the role of protein phosphorylation in the regulation of neuronal function. Annu. Rev. Neurosci. 6: 493-525.

Klein, M., and E. R. Kandel (1978) Presynaptic modulation of voltage-dependent $\mathrm{Ca}^{++}$current: Mechanism for behavioral sensitization in Aplysia californica. Proc. Natl. Acad. Sci. U. S. A. 75: 3512-3516.

Komai, Y., S. Matsukawa, and M. Satake (1971) Glycolipids in the nervous tissue of invertebrates. J. Biochem. 70: 367-369.

Kravitz, E. A., C. R. Slater, K. Takahashi, M. D. Bownds, and R. M. Grossfeld (1970) Excitatory transmission in invertebrates - Glutamate as a potential neuromuscular transmitter compound. In Excitatory Synaptic Mechanisms, P. Anderson and .J. K. S. Jansen, eds., pp. 85-93, Universitetsforlaget, Oslo.

Kravitz, E. A., S. Glusman, R. M. Harris-Warrick, M. S. Livingstone, T. Schwarz, and M. F. Goy (1980) Amines and a peptide as neurohormones in lobsters: Actions on neuromuscular preparations and preliminary behavioral studies. J. Exp. Biol. 89: 159-175.

Krnjevic, K., and R. Miledi (1958) Some effects produced by adrenalin upon neuromuscular propagation in rats. J. Physiol. (Lond.) 141: 291-304.

Kuba, K. (1970) Effects of catecholamines on the neuromuscular junction in the rat diaphragm. J. Physiol. (Lond.) 211: $551-570$.

Kuo, J. F., and P. Greengard (1970) Cyclic nucleotide-dependent protein kinases. IV. Isolation and partial purification of a protein kinase activated by guanosine $3^{\prime}, 5^{\prime}$-monophosphate. J. Biol. Chem. 245: 2493-2498.

Kuo, J. F., M. Shoji, and W. -N. Kuo (1978) Molecular and physiopathologic aspects of mammalian cyclic GMP-dependent protein kinase. Annu. Rev. Pharmacol. Toxicol. 18: 341355 .

Kupfermann, I. (1979) Modulatory actions of neurotransmitters. Annu. Rev. Neurosci. 2: 447-465.

Laemmli, U. K. (1970) Cleavage of structural proteins during the assembly of the head of bacteriophage T4. Nature (Lond.) 227: 680-685.

Laskey, R. A., and A. D. Mills (1977) Enhanced autoradiographic detection of ${ }^{32} \mathrm{P}$ and ${ }^{125} \mathrm{I}$ using intensifying screens and hypersensitized film. FEBS Lett. 82: 314-316.

Lemay, A., M. Deschenes, S. Lemaire, G. Poirier, L. Poulin, 
and F. Labrie (1974) Phosphorylation of adenohypophyseal plasma membranes and properties of associated protein $\mathrm{ki}$ nase. J. Biol. Chem. 249: 323-328.

Lemos, J. R., I. Novak-Hofer, and I. B. Levitan (1982) Serotonin alters the phosphorylation of specific proteins inside a single living nerve cell. Nature 298: 64-65.

Levitan, I. B., and S. H. Barondes (1974) Octopamine- and serotonin-stimulated phosphorylation of specific protein in the abdominal ganglion of Aplysia californica. Proc. Natl. Acad. Sci. U. S. A. 71: 1145-1148.

Levitan, I. B., C. J. Madsen, and S. H. Barondes (1974) Cyclic AMP and amine effects on phosphorylation of specific protein in abdominal ganglion of Aplysia californica; localization and kinetic analysis. J. Neurobiol. 5: 511-525.

Lingle, C. J., E. Marder, and J. A. Nathanson (1982) The role of cyclic nucleotides in invertebrates. In Handbook of Experimental Pharmacology, J. W. Kebabian and J. A. Nathanson, eds., Vol. 58, Part II, pp. 787-845, Springer-Verlag, Berlin.

Livingstone, M. S., S. F. Schaeffer, and E. A. Kravitz (1981) Biochemistry and ultrastructure of serotonergic nerve endings in the lobster: Serotonin and octopamine are contained in different nerve endings. J. Neurobiol. 12: 27-54.

Lowry, O. H., N. J. Rosebrough, A. L. Farr, and R. J. Randall (1951) Protein measurement with the Folin phenol reagent. J. Biol. Chem. 193: 265-275.

Matsumura, P., M. Silverman, and M. Simon (1977) Synthesis of $m o t$ and che gene products of Escherichia coli programmed by Col E1 plasmids in minicells. J. Bacteriol. 132: 996-1002.

Maynard, D. M., and J. H. Welsh (1959) Neurohormones of the pericardial organs of brachyuran Crustacea. J. Physiol. (Lond.) 149: 215-227.

Miyamoto, E., J. F. Kuo, and P. Greengard (1969) Cyclic nucleotide dependent kinases. III. Purification and properties of adenosine $3^{\prime}, 5^{\prime}$-monophosphate-dependent protein kinase from bovine brain. J. Biol. Chem. 244: 6395-6402.

Nimmo, H. G., and P. Cohen (1977) Hormonal control of protein phosphorylation. Adv. Cyclic Nucleotide Res. 8: 145266.

Otsuka, M., L. L. Iversen, Z. W. Hall, and E. A. Kravitz (1966)
Release of gamma-aminobutyric acid from inhibitory nerves in lobster. Proc. Natl. Acad. Sci. U. S. A. 56: 1110-1115.

Paris, C. G., V. F. Castellucci, E. R. Kandel, and J. H. Schwartz (1982) Protein phosphorylation, presynaptic facilitation and behavioral sensitization in Aplysia. Cold Spring Harbor Conf. Cell Prolif. 8: 1361-1375.

Pearse, A. G. E. (1980) Histochemistry: Theoretical and Applied, Ed. 4, Vol. 1, pp. 82-96, Churchill Livingston, Edinburgh.

Roberts, M. B., and W. H. Taylor (1978) Effect of cyclo-alkyl lactamimides upon human pepsins and pepsinogens. Clin. Sci. Mol. Med. 54: 181-185.

Schwarz, T. L., R. M. Harris-Warrick, S. Glusman, and E. A. Kravitz (1980) A peptide action in a lobster neuromuscular preparation. J. Neurobiol. 11: 623-628.

Seamon, K. B., W. Padgett, and J. W. Daly (1981) Forskolin: Unique diterpine activator of adenylate cyclase in membranes and in intact cells. Proc. Natl. Acad. Sci. U. S. A. 78: 3363-3367.

Sullivan, R., B. J. Friend, and D. L. Barker (1977) Structure and function of spiny lobster ligamental nerve plexuses: Evidence for synthesis, storage and secretion of biogenic amines. J. Neurobiol. 8: 581-605.

Sullivan, R. E. (1979) A proctolin like peptide in crab pericardial organs. J. Exp. Biol. 210: 543-552.

Tada, M., and A. M. Katz (1982) Phosphorylation of the sarcoplasmic reticulum and sarcolemma. Annu. Rev. Physiol. 44: 401-423.

Takeuchi, A., and N. Takeuchi (1965) Localized action of gamma-aminobutyric acid on the crayfish muscle. J. Physiol. (Lond.) 177: 225-238.

Welsh, J. H., and M. Moorhead (1960) The quantitative distribution of 5 -hydroxytryptamine in the invertebrates, especially in their nervous systems. J. Neurochem. 6: 146-169.

Wiech, N. L., B. W. Siegel, and A. C. Hagan (1978) RMI 12330A: An inhibitor of adenylate cyclase activity. (Abstr.). Adv. Cyclic Nucleotide Res. 9: 726.

Wiersma, C. A. G., and S. H. Ripley (1952) Innervation patterns of crustacean limbs. Physiol. Comp. Oecol. 2: 391-405. 